\title{
Tumour initiation, store-operated calcium entry (SOCE) and apoptosis: cyclic nucleotide dependence
}

\author{
Wynford R. Williams \\ Faculty of Life Sciences and Education, University of South Wales, Cardiff, United Kingdom
}

\begin{abstract}
Chemical instigators and modulators of tumourigenesis influence cell signal transduction pathways. Cyclic nucleotides and steroid hormones may contribute to the process of carcinogenesis or provide protection via apoptotic mechanisms. Although several pharmacologic classes of compounds influence cyclic nucleotide levels markedly, less is known about the class effects of promoters and blockers of tumourigenesis and apoptosis. This molecular modeling study uses cyclic nucleotide templates to investigate relative molecular similarity within compounds modulating tumourigenesis and apoptosis. Findings, in respect of superimposition and molecular fit of the investigated compounds, are related to their individual effects on cyclic nucleotide pharmacology. Modulators of tumourigenesis and estrogen receptor sub-type ligands relate to cyclic nucleotide structure. Estradiol and GPER ligands provide a similar pattern of fit to adenine nucleotide. Chemically diverse modulators of apoptosis, including $\mathrm{K}^{+}$channel ligands, fit to different components of cyclic nucleotide structure. Compounds modulating $\mathrm{Ca}^{2+}$ entry and IP3 receptors relate structurally to the nucleotide dioxaphosphinin moiety. Relative molecular similarity within the structures of apoptosis and tumourigenesis modulators identifies a unifying property within chemically disparate compounds. The ubiquitous generation of oxidative stress and ROS in cells by apoptosis modulating compounds may relate to the disruption of cyclic nucleotide regulated homeostasis mechanisms.
\end{abstract}

Key words: Cyclic nucleotides - Apoptosis - Tumourigenesis - SOCE

\section{Introduction}

Reliance on chemotherapy and radiation for cancer therapy is currently balanced by the aims of boosting natural immune defences and modulating tumour cell apoptosis/death mechanisms to the benefit of patients. Much of our knowledge of tumour initiation and development derives from the 2-stage animal model of carcinogenesis (Abel et al. 2009). In this model, simple chemicals introduced to epidermal cells have an opportunity to interact with cell membrane components and cytoplasmic signal transduction systems before reaching nuclear material. Potential targets of tumour initiators include cyclic nucleotides, kinases, phosphodiesterases (Saravani et al. 2012; Levin and Hammes 2016) ion channels and steroid receptors (Teisseyre et al. 2015; Levin and

Correspondence to: Wynford R. Williams, School of Care Sciences, Faculty of Life Sciences and Education, University of South Wales, Cardiff, CF37 1DL, United Kingdom

E-mail: Robert.Williams2@southwales.ac.uk
Hammes 2016), in addition to compounds participating in the biochemical cascades prosecuting mitochondrial and cell surface death receptor pathways (Derakhshan et al. 2017).

Steroid hormones drive cell proliferation by activating nuclear receptors and the estrogen receptors that regulate G-proteins (GPER) (Capper et al. 2016; Feldman and Limbird 2017). GPER, linked to cancer progression and poor prognosis in breast cancer patients, facilitate rapid signaling via cell membrane receptors and ion channels (Prossnitz and Hathoway 2015; Machuki et al. 2018). Kow and Pfaff have reported on the complex targeting of all major categories of ion channel by estrogenic agents, their interaction with many signaling components and the likelihood of a common underlying mechanism (Kow and Pfaff 2018). Potassium channels represent the largest group of ion channels involved in cell proliferation and death events (Jehle et al. 2011; McFerrin et al. 2012; Ge et al. 2014; Teisseyre et al. 2015).

The NO/cGMP pathway influences cell calcium homeostasis markedly through processes involving voltage- and store-operated channels, IP3, ryanodine and calcium-sensing 
receptors (Watson et al. 1999; Greenberg et al. 2016). NO and cGMP also act independently to modulate capacitive $\mathrm{Ca}^{2+}$ entry (Watson et al. 1999), $\mathrm{Ca}^{2+}$ sequestration (Ishikawa et al. 2003) and $\mathrm{Ca}^{2+}$ loading of the sarcoplasmic reticulum (Bazan-Perkins 2012). cGMP has a dual action on $\mathrm{Ca}^{2+}$ entry in pancreatic acini, attributable to the $\mathrm{Ca}^{2+}$ sensitivity of NOS with respect to cytosolic and store $\mathrm{Ca}^{2+}$ (Xu et al. 1994). IP3 receptors link with extracellular signals and the phospholipase $\mathrm{C}$ pathway to facilitate the rapid passage of $\mathrm{Ca}^{2+}$ from endoplasmic reticulum to cytosol and stimulation of store-operated calcium entry (SOCE) (Thillaiappan et al. 2019). cGMP/ PKG signaling regulates IP3R activity, promoting endoplasmic reticulum stress and apoptosis of cone photoreceptors in mice deficient in cyclic nucleotide-gated (CNG) channels (Ma et al. 2015). SOCE modulates malignant transformation and tumour progression, though the effects are inconsistent in different cell types and tumour stages (Xie et al. 2016). A functional link exists between endoplasmic reticulum distress, mitochondrial ROS production and damage to chemical and membrane infrastructure, that contributes to the milieu facilitating cell death (Redza-Dutordoir and Averill-Bates 2016).

The influences of cyclic nucleotides on apoptosis are inconsistent. Pro-apoptotic and anti-apoptotic properties of cAMP depend, to a considerable degree, on cell type (Insel et al. 2012). Intracellular cAMP receptors are amplified in breast cancer; protein kinase A (PKA) and EPAC, a guanine nucleotide exchange factor associated with PKA-independent responses, determine the fate of tumour cells (Kumar et al. 2017). Elevation of Jurkat cell cAMP potentiates apoptosis by enhancing cleavage of caspase- 8 and augmenting the processing of Fas effector proteins (Naderi and Blomhoff 2008). In contrast, agents promoting cAMP formation in promonocytic leukemia cells attenuate the generation of apoptosis by etoposide (Garcia-Bermejo et al. 1998). One anti-apoptotic mechanism of cAMP involves the phosphorylation of pro-apoptotic proteins (Fatemi et al. 2015).

Guanylate cyclase activity and cGMP levels are abnormal in leukemic cells, lymphoid, ovarian and colorectal tumours (Orbo et al. 2007; Rappaport and Waldman 2018). Guanine nucleotide depletion and guanosine addition respectively induce and prevent apoptosis in neuroblastoma cell lines (Messina et al. 2004). Basal cGMP levels promote ovarian cancer cell survival by regulating p53 function (Fraser et al. 2006). Elevated cGMP and abnormal CNG channel expression results in photoreceptor oxidative stress and apoptosis in mouse retina (Sharma and Rohrer 2007; Wang et al. 2017). In neutrophils and breast cancer cell lines, $\mathrm{PKG}$ has a positive association with apoptosis (Brunetti et al. 2002; Fallahian et al. 2011; Saravani et al. 2012). However, estrogen-induced apoptosis of breast cancer epithelial cells is blocked by the NO/cGMP/PKG pathway (Kastrati et al. 2010). Tumour cell survival is also influenced by the concentration dependent effects of nitric oxide (NO). NO is protective for PC12 cells against the activation of caspase proteases and cell death but apoptotic for vascular smooth muscle cells (Kim et al. 2008).

As deregulation of cyclic nucleotide signaling is an early event in tumourigenesis, cell signal activation remains an active strategy for cancer prevention and treatment (Fajardo et al. 2014). One model of oncogenesis implicates nucleotide insufficiency in contributing to replication stress and genomic instability resulting from oncogene-induced cell proliferation (Bester et al. 2011). The assumption that the widely diverse chemicals initiating and promoting carcinogenesis have multiple targets need not be the case; rationalisation of their properties may simplify strategies of therapeutic intervention. cGMP and cAMP have well established roles as second messengers in cell signal transduction events. In terms of molecular structure, cyclic nucleotides could be considered as intermediate forms between receptor agonists, such as catecholamine hormones, and steroid structures. Molecular similarity provides some insight into mechanisms of signal transduction, particularly with regard to the potential of ligands to influence nucleotide conformational change This study uses a computational program to compare the molecular structures of cyclic nucleotides with tumour initiators, modulators of cell apoptosis and SOCE, to better understand processes underlying the initiation and suppression of carcinogenesis at the earliest stage.

\section{Materials and Methods}

The compounds of principle interest to this study are listed in Table 1. Molecular formulae of the compounds are from IUPHAR (Harding et al. 2018) and Pubchem (http://pubchem. ncbi.nlm.nih.gov) databases. Estrogen receptor subtypeselective ligands are reviewed by Paterni and co-authors (Paterni et al. 2014). The Nemesis software program (Oxford Molecular version 2.1) is used to build molecular structures from contents of the program fragment file and minimise structures by conformational analysis. The compound structures used for fitting are minimum energy conformers in an uncharged form. Anti-conformers of cAMP and cGMP are described by the torsion angle C8N9C1'O9 $-33^{\circ}$ (see Fig. 1). The computational program fits paired molecular structures on a three-point basis. The fitting points, comprised of atoms of similar type and partial charge within compound and nucleotide structures, are identified in the text with respect to nucleotide labels. Colour-coded atoms in the Figures identify ligand-fitting points: carbon - green, nitrogen - blue, oxygen - red, sulphur - yellow (see online version for color figures). To improve on presentation, bond order within the molecular structures is not shown and nucleotide structures are cropped. The Nemesis program computes goodness-of-fit values, in respect of inter-atomic distance at each fitting point and root mean square (RMS) value. 
Table 1. Agents modulating apoptosis: reference sources and mechanisms

\begin{tabular}{|c|c|c|c|c|c|}
\hline \multirow{2}{*}{ Compound } & \multirow{2}{*}{ Induces apoptosis } & \multirow{2}{*}{$\begin{array}{l}\text { Protects against } \\
\text { apoptosis }\end{array}$} & \multicolumn{3}{|c|}{ Mechanisms } \\
\hline & & & Oxidative stress/ROS & cAMP & cGMP/NO \\
\hline Arsenic trioxide & Chen et al. 2015 & - & $\mathrm{x}$ & $\mathrm{x}$ & \\
\hline Ascorbic acid & Lim et al. 2016 & Witenberg et al. 1999 & $\mathrm{x}$ & & \\
\hline Aspirin & Raza and John 2012 & Jian et al. 2016 & $\mathrm{x}$ & & \\
\hline BCNU & Yamaguchi et al. 2010 & Petak et al. 1998 & & & \\
\hline camptothecin & Ha et al. 2009 & - & $\mathrm{x}$ & & \\
\hline Carnosic acid & Zhang et al. 2017 & Das et al. 2018 & $\mathrm{x}$ & & \\
\hline Ceramide (C6) & Matsunaga et al. 2004 & Agudo-Lopez et al. 2011 & $\mathrm{x}$ & & \\
\hline Curcumin & Mortezaee et al. 2019 & Benzer at al. 2018 & $\mathrm{x}$ & & $\mathrm{x}$ \\
\hline Cyclopiazonic acid & Kang et al. $2011^{1}$ & Harriman et al. $2002^{2}$ & $\mathrm{x}$ & & \\
\hline Cytosine arabinoside & Kanno et al. 2004 & - & $\mathrm{x}$ & & \\
\hline Dexamethasone & Deng et al. 2019 & Ruiz et al. 2002 & $\mathrm{x}$ & & \\
\hline Dichlorvos & Salem et al. 2016 & - & $\mathrm{x}$ & & \\
\hline Dimethylbenzanthracene & Tsai-Turton et al. 2007 & - & $\mathrm{x}$ & & \\
\hline Docosahexaenoic acid & Kang et al. 2010 & Zhang et al. 2018 & $\mathrm{x}$ & & \\
\hline Doxorubicin & Octavia et al. 2017 & - & $\mathrm{x}$ & & \\
\hline $17-\beta$ estradiol & Yang et al. 2017 & Marathe et al. 2012 & & & $\mathrm{x}$ \\
\hline Folic acid & - & Octavia et al. 2017 & $\mathrm{x}$ & & \\
\hline Gallic acid & Lin \& Chen 2017 & Chandrasrkhar et al. 2018 & $\mathrm{x}$ & & \\
\hline Genistein & Lee \& Park 2013 & Luo et al., 2018 & $\mathrm{x}$ & $\mathrm{x}$ & \\
\hline Glucose & Zhang Y et al. 2019 & - & $\mathrm{x}$ & & \\
\hline 27-hydroxycholesterol & Marwarha et al 2017 & Riendeau \& Garenc 2009 & $\mathrm{x}$ & & \\
\hline 6-hydroxydopamine & Eftekhar-Vaghefi et al. 2015 & - & $\mathrm{x}$ & $\mathrm{x}$ & \\
\hline Isopimpinellin & Patil et al 2013 & - & & & \\
\hline a-Lipoic acid & - & Yang Y et al. 2012 & $\mathrm{x}$ & & \\
\hline Methotrexate & AlBasher et al. 2019 & - & $\mathrm{x}$ & & \\
\hline MNU & Emoto et al. 2016 & - & $\mathrm{x}$ & & \\
\hline Nitric oxide & Bonavida \& Garban 2015 & Yoo et al. 2018 & $\mathrm{x}$ & & $\mathrm{x}$ \\
\hline Nordihydroguaiaretic acid & Hernandez-Damian et al. 2014 & Culver et al. 2005 & $\mathrm{x}$ & & \\
\hline Palmitate & Kim et al. 2010 & - & $\mathrm{x}$ & & \\
\hline Paxilline & Kang et al. $2011^{1}$ & - & $\mathrm{x}$ & & \\
\hline Phytic acid & - & da Silva et al. 2019 & $\mathrm{x}$ & & \\
\hline PMA & Itsumi et al. 2014 & Bonavita et al. 2003 & & & \\
\hline pregnenolone & Xiao et al. 2014 & Leskiewicz et al. 2008 & & & \\
\hline progesterone & Nguyen \& Syed 2011 & Cai et al. 2015 & $\mathrm{x}$ & & \\
\hline Prostacyclin & Li et al. 2004 & Pozner et al. 2005 & & $\mathrm{x}$ & \\
\hline Quercetin & Lee et al. 2015 & Suganya et al. 2018 & $\mathrm{x}$ & & $\mathrm{x}$ \\
\hline Resveratrol & Gu et al. 2016 & Lu et al. 2018 & $\mathrm{x}$ & & \\
\hline Retinoic acid & Wang et al. 2014 & Khafaga \& El-Sayed 2018 & $\mathrm{x}$ & & \\
\hline Silibinin & Ham et al. 2018 & Yang et al. 2018 & $\mathrm{x}$ & & \\
\hline Sulforaphane & Choi 2018 & - & $\mathrm{x}$ & & \\
\hline Testosterone & Lopes et al. 2014 & Kang et al. 2018 & $\mathrm{x}$ & & \\
\hline Tetracaine & Lee et al. 2009 & - & $\mathrm{x}$ & & \\
\hline Thapsigargin & Kang et al. $2011^{1}$ & Harriman et al. $2002^{2}$ & $\mathrm{x}$ & & $\mathrm{x}$ \\
\hline Vitamin A & Klamt et al 2008 & Blomhoff $2004^{3}$ & $\mathrm{x}$ & & \\
\hline Vitamin D & Koren et al. 2001 & Shymanskyy et al. 2016 & $\mathrm{x}$ & & \\
\hline Vitamin E & - & de Arriba et al. 2009 & $\mathrm{x}$ & & \\
\hline
\end{tabular}

BCNU, 1,3-bis(2-chloroethyl)-N-nitrosourea; DMBA, dimethylbenzanthracene; MNU, N-methyl-N-nitrosourea; PMA, phorbol myristate acetate; ${ }^{1}$ compound sensitises cells to tumour necrosis factor-related apoptosis-induced ligand (TRAIL); ${ }^{2}$ protection via nuclear receptor and transcription; ${ }^{3}$ compound causes $\mathrm{Ca}^{2+}$ depletion prior to addition of toxicant. 


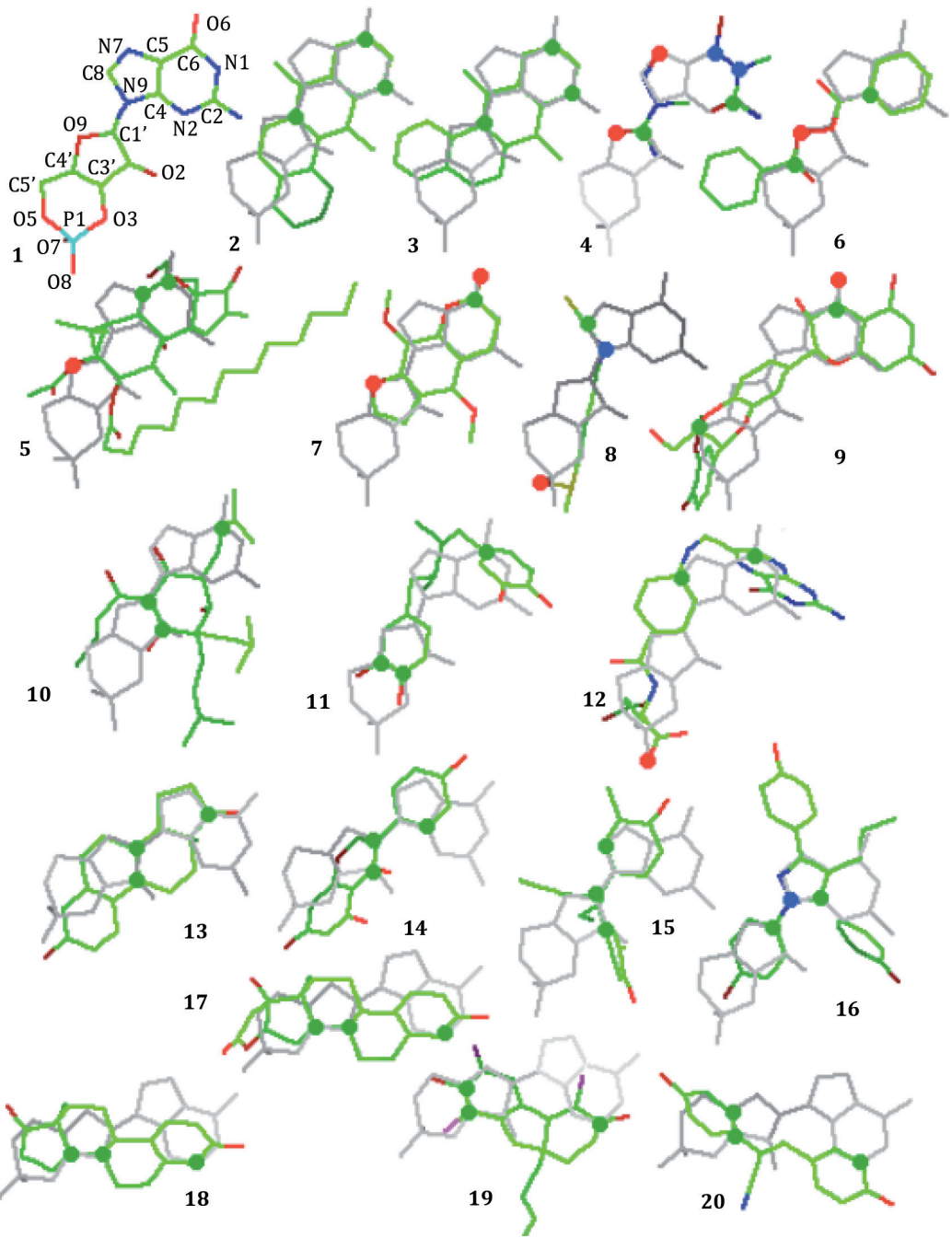

Figure 1. Tumour initiators, promoters and estrogen receptor (ER) ligands: fits to nucleotide structures (grey) cGMP (1-16), cAMP (17-20). (1) cyclic guanosine monophosphate (cGMP), (2 and 3) 7,12-dimethylbenz(a)anthracene (DMBA), (4) N-methyl-N-nitrosourea (MNU), (5) phorbol12-myristate-13-acetate (PMA), (6) benzylperoxide, (7) isopimpinellin, (8) sulforaphane, (9) silibinin, (10) hexahydrocolupulone, (11) nordihydroguaiaretic acid, (12) folic acid, (13 and 18) estradiol, (14) genistein, (15) diphenylmethane derivative, (16) propylpyrazoletriol, (17) 16aLE, (19) SERM-ßeta2, (20) (R)-DPN.

\section{Results and Discussion}

\section{Tumour initiators and modulators}

The dimethylbenzanthracene (DMBA) structure in Figure 1 (templates 2 and 3 ) approximates to the molecular size of cGMP (1) in contrast to the structure of the tumor promoter $\mathrm{N}$-nitroso-N-methylurea (MNU) (4). The proportion of the nucleotide structure influenced by DMBA and MNU is made more equitable when two structures of MNU are superimposed on different regions of the nucleotide, as given in the Figure. MNU, phorbol myristate acetate (PMA) (5) and benzyl peroxide (6) structures are more similar to the nucleotide in their distribution of partial charge, in comparison to the carbon scaffold of DMBA. Isopimpinellin (7), sulforaphane (8) and silibinin (9), antagonists of tumour initiation and promotion, provide nucleotide $\mathrm{O} 6$ or $\mathrm{O} 7$ fitting points. Hexahydrocolupulone (10), nordihydroguaiaretic acid (11) and folic acid (12) protect against skin changes in the mouse two-step skin carcinogenesis model (Hsu et al. 2013; Rahman et al. 2015; Koul et al. 2018).

A subtle difference of 2 amino acid residues within the ligand-binding receptor cavities of estrogen receptor subtypes ER $\alpha$ and ER $\beta$ limits the design of selective ligands (Paterni et al. 2014). A cAMP template is used for fitting ER $\beta$ agonist structures, as their effects are associated with the cAMP/PKA pathway (Wang et al. 2018). The agonists of ER $\alpha(13-16)$ and ER $\beta$ (17-20) provide two patterns of fit to the nucleotide structures. Estradiol (17 $\beta$-estradiol) and ER $\alpha$ agonists fit to the imidazole moiety and ribose ring of cGMP. Estradiol and ER $\beta$ agonists fit to the aminopyrimidine moiety and ribose ring of cAMP. These fitting points contribute to different alignments of ER $\alpha$ and ER $\beta$ ligands on the nucleotide structures. Goodness of fit values are less than $0.16 \AA$ (interatomic distance) and $0.0193 \AA$ (RMS) for structures $1-12$, and less than $0.16 \AA$ (interatomic distance) and $0.0258 \AA$ (RMS) for structures 13-20. 


\section{GPER receptor ligands}

Estrogen modulation of cell cAMP and $\mathrm{Ca}^{2+}$ can be explained in terms of regulation at GPER receptors. Estrogen deficiency compromises the coupling of $\beta$-adrenergic receptors to $G_{s}$ and $G_{i}$ alpha proteins (Prossnitz and Hathaway 2015; Hou et al. 2018). On this account, an ATP template is used here to compare estrogen and GPER ligand structures (Fig. 2). The fitting points of potent and specific GPER agonists 1-[4-(6-bromobenzo[1,3)dioxol-5-yl)-3a,4,5,9btetrahydro-3H-cyclopentya [c)quinolin-8-yl)-ethanone (G1), GPER-L1 and GPER-L2, focus on the ribose ring $\left(\mathrm{O} 3, \mathrm{C}^{\prime}\right)$ of ATP and linkage to the purine base $\left(\mathrm{Cl}^{\prime}, \mathrm{N} 9, \mathrm{C} 4\right)$ whereas antagonists (4 and 5) fit solely to the purine base. The fits of agonist structures (1-3) introduce a cyclic ring or ring substituent in the vicinity of nucleotide $\mathrm{O} 3$, in contrast to the antagonists ethyl3-[5-(2-ethoxycarbonyl-1-methylvinyloxy)1-methyl-1H-indol-3-yl)but-2-enoate (MIBE) (4) and 7-(quinoxalin-2-ylamino)-4H-benzo[b)pyrralo[1,2-d) [1,4) oxazin-4-one (PBX-1) (5). Estradiol (6a-6l) provides many relevant fits to the ATP template with interatomic distance values in the range of $0.02 \AA-0.18 \AA$ (RMS values $<0.0333 \AA$ ). Alternative fits of estradiol, using $\mathrm{C} 4$ and $\mathrm{C} 5$ fitting points, or with fitting points located solely on the purine ring, are not given. Estradiol (templates 6a, 6b, 6c) completely or partially replicates the fits of the GPER agonist structures. This may have functional significance at receptor proteins, in the displacement or substitution of nucleotide. Steric hindrance in the region of nucleotide $\mathrm{O} 2$ and $\mathrm{O} 3$ hydroxyl groups may modulate the processing of ATP by adenyl cyclase. This potential for agonist-nucleotide interaction is represented here by the fits of the $\beta$-adrenergic receptor ligands isoprenaline (7) and R-O363 (8). The former structure has the potential to displace the nucleotide and promote cyclisation, whereas targeting of the $\mathrm{O} 3$ group involved in the cyclisation process by the antagonist may block the process. Template 6 e gives an isoprenaline-like fit of estradiol.

The bonding region between nucleotide ribose and purine rings includes an intramolecular space defined by the torsion angle $\mathrm{C}^{2} \mathrm{C} 1^{\prime} \mathrm{N} 9 \mathrm{C} 4$. This site is blocked by the fit of the

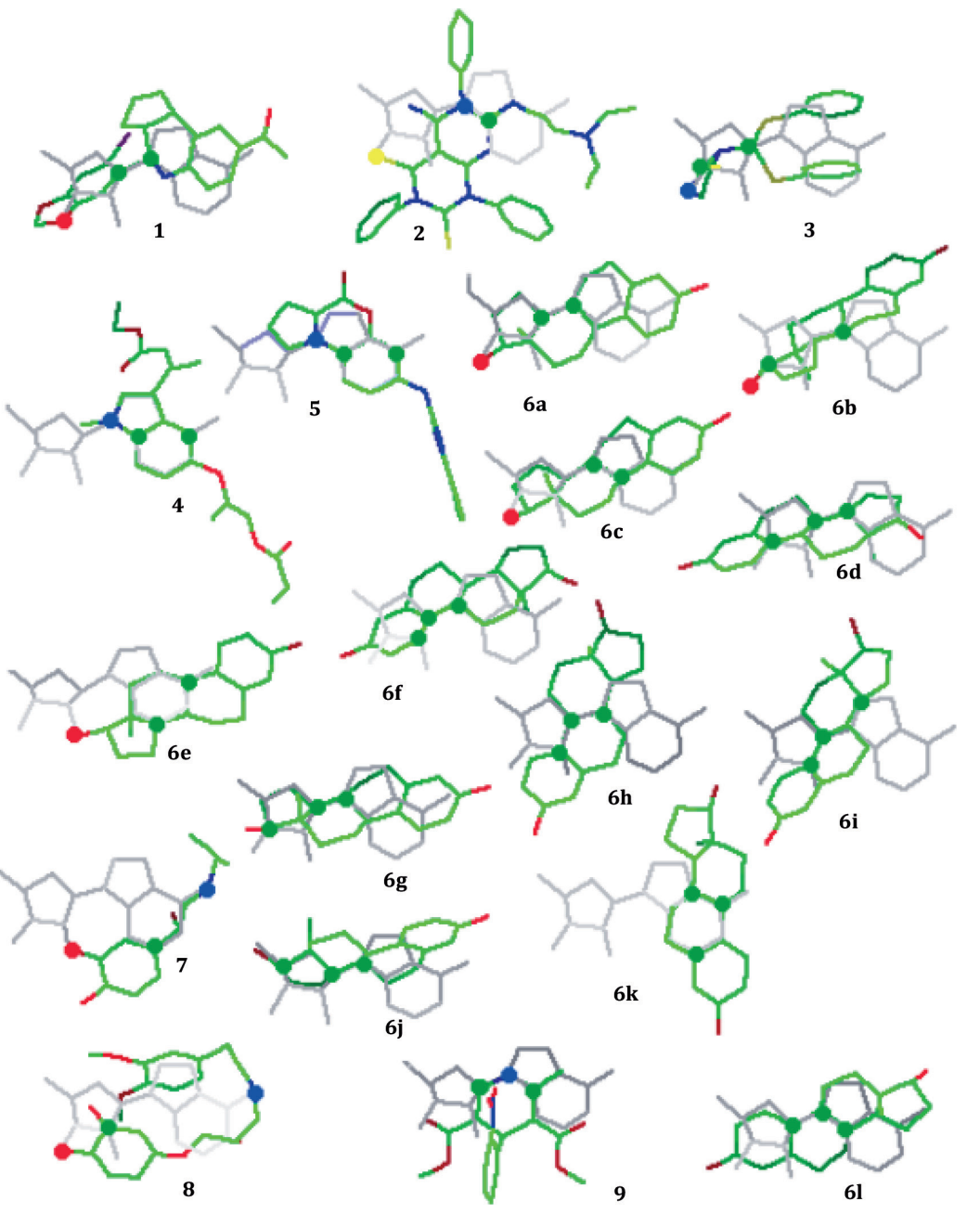

Figure 2. G-protein coupled estrogen receptor (GPER) ligands: fits to ATP (grey). (1) G1, (2) GPER-L1, (3) GPER-L2, (4) MIBE, (5) PBX-1, (6 a-l) estradiol, (7) isoprenaline, (8) Ro-363, (9) nifedipine. 
calcium channel blocker nifedipine (9) and replicated by the fit of estradiol (61). GPER agonist G1 opens the nifedipine sensitive L-type calcium channel in rat myometrium cells (Tica et al. 2011). GPER (GPR30) co-localise with other pharmacologic classes of $G_{\alpha}$ protein ligands, modulating serotonin and neuronal acetylcholine receptors (Xu et al. 2009; Hammond et al. 2011). Estrogen also modulates the strength of antinociception provided by opioid receptor agonists (Robinson et al. 2016). The estrogen templates 6b, $6 \mathrm{f}, 6 \mathrm{~g}, 6 \mathrm{~h}$ and $6 \mathrm{j}$ use fitting points common to ligands acting at acetylcholine, serotonin and opiate receptors (Williams 2018).

\section{Modulators of apoptosis}

Figure 3 gives a chemically diverse range of apoptosis modulating compounds providing good fits to the cGMP structure. The best of the alternative fits of testosterone ( 1 and 2) has nucleotide $\mathrm{O} 6$ and $\mathrm{O} 7$ fitting points. Nucleotide oxygens also contribute to the fits of dexamethasone (3), prostacyclin (6) and camptothecin (10). Nucleotide C6 is a common fitting point of various carbons in the structures of dexamethasone (3), pregnenolone (4), 27-hydroxycholesterol (5), doxorubicin (13), curcumin (14), carnosic acid (16), vitamin A (7), palmitate (8) and docosahexaenoic acid (9). Methotrexate (12) quercetin (15) and cytosine arabinoside (17) have some fitting points in common on the nucleotide guanine and ribose rings. Goodness of fit values of the structures in Figure 3 are less than $0.16 \AA$ (interatomic distance) and $0.0250 \AA$ (RMS).

The $\mathrm{BK}_{\mathrm{Ca}}$ channel antagonists paxilline (1), progesterone (2) and genistein (3) fit across the length of the cGMP structure (Figure 4). Paxilline, in common with thapsigargin and cyclopiazonic acid, enhances apoptosis mediated by TRAIL (tumour necrosis factor-related apoptosis-induced ligand) and regulates the cell cycle of neuroblastoma cells (Kang et al. 2011; Maqoud et al. 2018). Progesterone and genistein induce apoptosis and protect against apoptosis (Table 1);

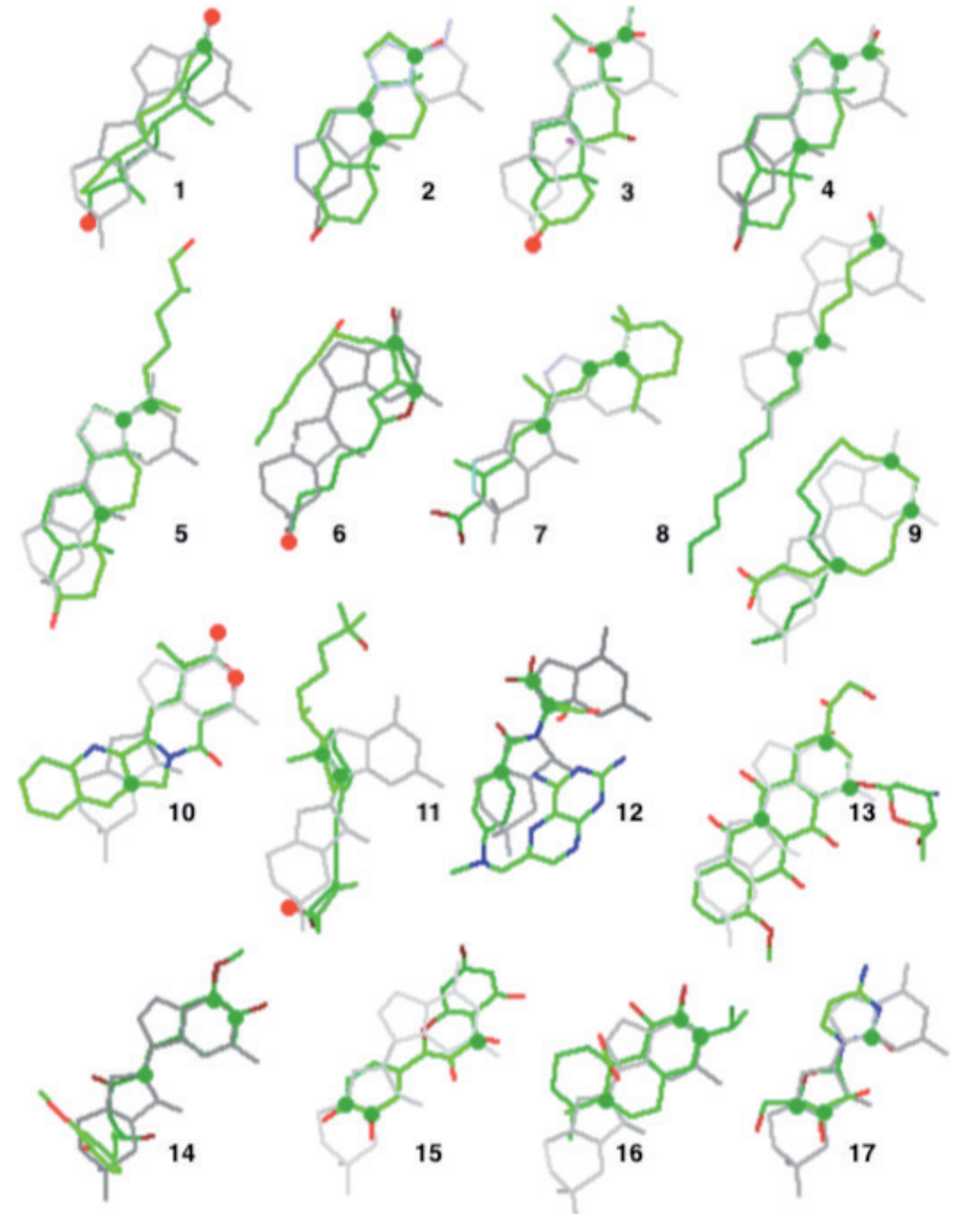

Figure 3. Compounds modulating apoptosis: fits to cGMP (grey). (1 and 2) testosterone, (3) dexamethasone, (4) pregnenolone, (5) 27-hydroxycholesterol, (6) prostacyclin, (7) all trans-retinoic acid, (8) palmitic acid, (9) docosahexaenoic acid, (10) camptothecin, (11) $1,25(\mathrm{OH})_{2}$ vitamin $\mathrm{D}$, (12) methotrexate, (13) doxorubicin, (14) curcumin, (15) quercetin, (16) carnosic acid, (17) cytosine arabinoside. 


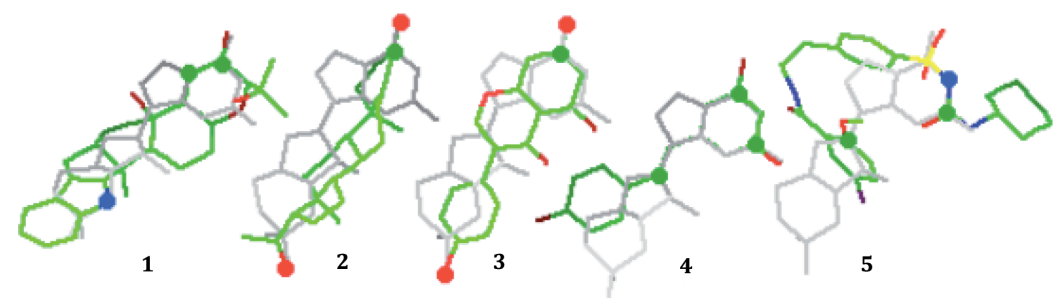

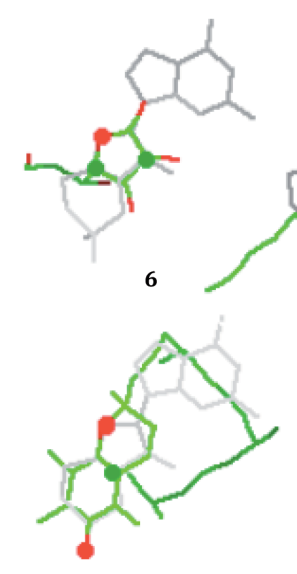

10

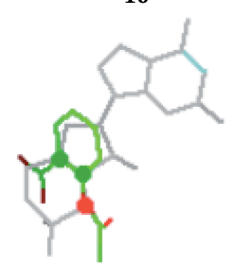

14
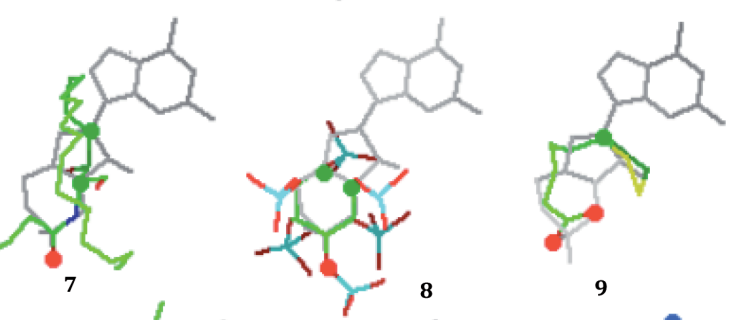

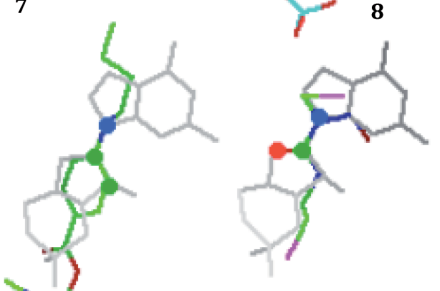

12

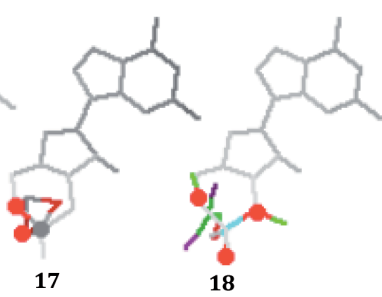

Figure 4. Compounds modulating apoptosis: fits to nucleotide structures (grey) cGMP or cAMP (13). (1) paxilline, (2) progesterone, (3) genistein, (4) resveratrol, (5) glibenclamide (6) ascorbic acid, (7) ceramide, (8) phytic acid, (9) a-lipoic acid, (10) vitamin E, (11) tetracaine, (12) BCNU, (13) 6-hydroxydopamine, (14) aspirin, (15) glucose-6-phosphate, (16) gallic acid, (17) arsenic trioxide, (18) dichlorvos. both compounds have the same O6-O8 atomic distance, nucleotide fit and $\mathrm{BK}_{\mathrm{Ca}}$ channel blocking activity. Resveratrol (4), an inhibitor of $\mathrm{Kv}$ and $\mathrm{K}_{\mathrm{ATP}}$ channels, stimulates insulin secretion (Chen et al. 2007) and displaces the $\mathrm{K}_{\mathrm{ATP}}$ channel antagonist glibenclamide (5) from the sulphonylurea receptor (Hambrock et al. 2007).

Figure 4 (6-18) also introduces a group of oxygen rich compounds with apoptosis modulating properties and a more restricted fit to the cGMP structure. Ascorbic acid (6) provides an alternative fit (not shown) based on the fitting points of 1,3-bis(2-chloroethyl)-N-nitrosourea (BCNU) (12). Ceramide (7), $\alpha$-lipoic acid (9), vitamin E (10), glucose6-phosphate (15) and gallic acid (16) have fitting points on the nucleotide phosphobicyclic ring. The fits of phytic acid (8), aspirin (14), arsenic trioxide (17) and dichlorvos (18) to the terminal cyclised ring are more restricted. Lipoic acid inhibits apoptosis caused by high glucose levels in cell culture (Yang et al. 2012). Phosphorylation of glucose to glucose-6-phosphate is an initial step in glucose utilisation and up-regulation of glucose-6-phosphate dehydrogenase promotes $\beta$-cell apoptosis (Lee et al. 2011). Arsenic trioxide influences cell $\mathrm{Ca}^{2+}$ by inhibiting the IP3 receptor and sarcoplasmic reticulum $\mathrm{Ca}^{2+}$ ATPase (Hsu et al. 2012; Zhang et al. 2016). The structures of dichlorvos and arsenic trioxide provide the minimum and maximum goodness of fit values of compounds given in Figure 4: interatomic distance values $<0.05 \AA$ and $<0.18 \AA$, RMS $0.0028 \AA$ and $0.0347 \AA$, respectively. The fit of the apoptosis-inducing agent 6-hydroxydopamine (13) is to adenine cyclic nucleotide.

There is considerable interaction between the above compounds in cell cultures. Arsenic trioxide induced apoptosis is enhanced by ascorbate, docosahexaenoic acid, genistein, quercetin, retinoic acid (Michel et al. 2003; Baumgartner et al. 2004; Sanchez et al. 2009; Shen et al. 2012; Wei et al. 2014) and ameliorated by resveratrol (Chen et al. 2015). cAMP prevents apoptosis induction by palmitate, docosahexaenoic acid, arsenic trioxide and doxorubicin, in different cell lines, by promoting phosphorylation of PKA target proteins and the cAMP-GEF pathway (Kwon et al. 2004; Miura et al. 2005; Safa et al. 2014; Fatemi et al. 2015). 6-Hydroxydopamine induced apoptosis is reduced by NO, cAMP, curcumin, phytic acid and gallic acid (Ha et al. 2003; Fujita et al. 2006; Jaisin et al. 2011; Xu et al. 2011; Chandrasekhar et al. 2018). Vitamin E blocks apoptosis induction by 7 - $\beta$-hydroxycholesterol 
and docosahexaenoic acid in human cell lines (Lyons et al. 2001; Xiong et al. 2012). Quercetin protects against methotrexate and dichlorvos induced oxidative stress and apoptosis in rats and HCT116 cells, respectively (Erboga et al. 2015; Salem 2016). Camptothecin induced apoptosis is enhanced by aspirin and inhibited by dexamethasone (Alfonso et al. 2009; Qian et al. 2009). Retinoate augments or synergises with the actions of 8-Cl-cAMP, carnosic acid and vitamin $\mathrm{D}$ in the growth inhibition or apoptosis of cancer cells (Srivastava et al. 2000; Steiner et al. 2001; Sha et al. 2013). Vitamins A and D induce resistance to apoptosis promoted by idarubicin, an analogue of doxorubicin (Ketley et al. 1997). Apoptosis and cardiotoxicity resulting from doxorubicin is reduced by curcumin via attenuation of mediator and enzyme activity, including iNOS (Benzer et al. 2018). Cytosine arabinoside mimics the neuroprotective action of cAMP on dopaminergic neurons (Mourlevat et al. 2003). One property unifying these disparate compounds is their relative molecular similarity to cyclic nucleotide structure, identified in Figures 3 and 4 . Several of the above interactive compounds share fitting points and/or superimpose on the nucleotide structures with similar fits.

Table 1 lists the above compounds with established apoptosis modulating properties via effects on second messengers and oxidative stress/ROS mechanisms. That so many of these compounds both induce and inhibit apoptosis, by similar mechanisms in different cell types, is surprising. In megakaryocytes, for example, prostacyclin induced cAMP antagonises apoptosis promoted by NO (Pozner et al. 2005), yet prostacyclin induced cAMP in VSMC cells initiates apoptosis ( $\mathrm{Li}$ et al. 2004). Arsenic trioxide also promotes cAMP generation (Abudoureyimu and Muhemaitibake 2017) although, unlike the adenyl cyclase stimulating properties of epinephrine, forskolin and prostacyclin, the mechanism is obscure. The anti-apoptotic effects of estradiol and quercetin, on osteocytes and pancreatic $\beta$-cells respectively, are NO/cGMP mediated; cGMP mimicking the effects of estradiol on osteocytes (Marathe et al. 2012; Suganya et al. 2018). In a breast epithelial cell line, NO/cGMP signaling blocks estradiol induced apoptosis (Kastrati et al. 2010).

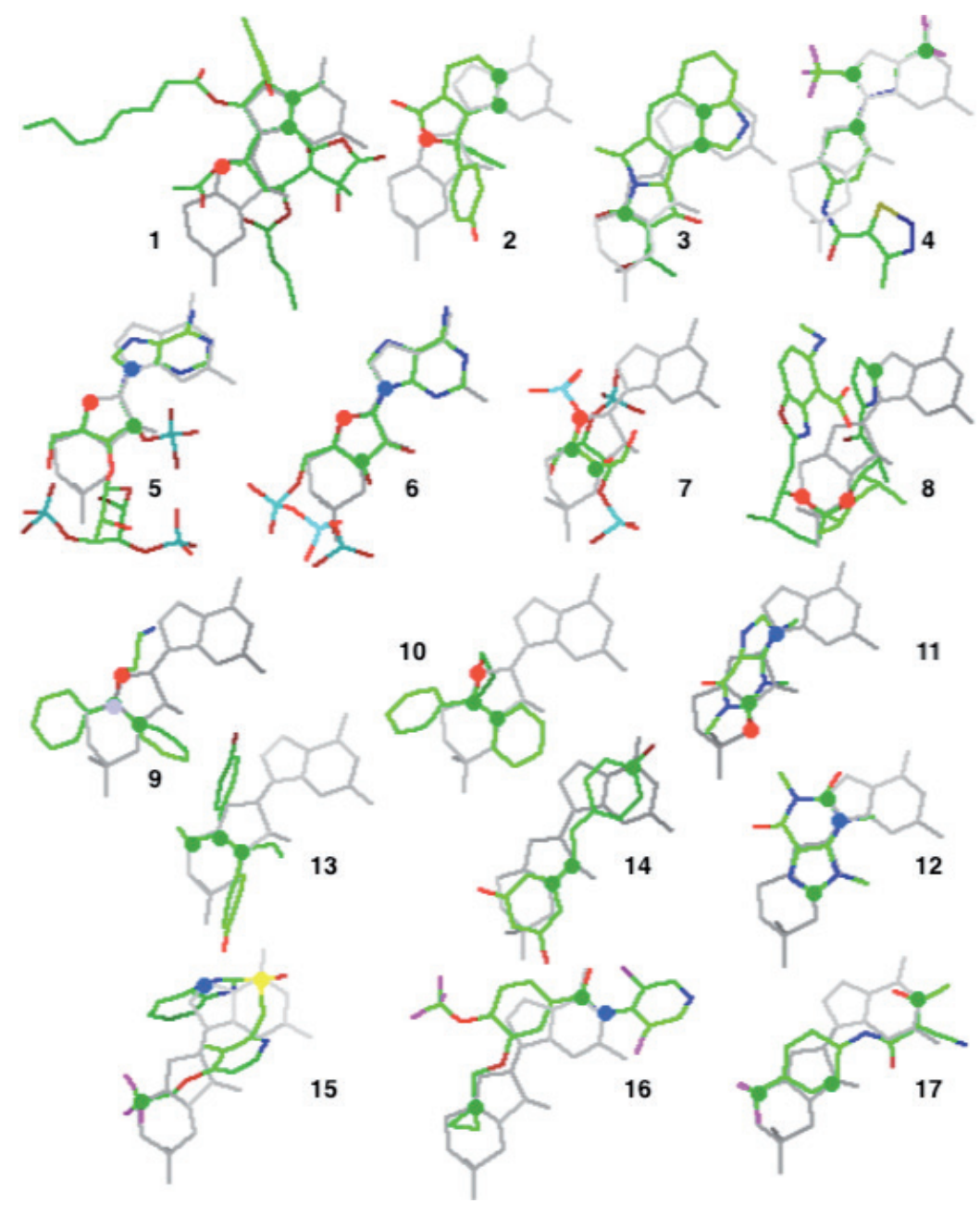

Figure 5. Compounds modulating storeoperated calcium entry (SOCE): fits to cGMP (grey). (1) thapsigargin, (2) phenolphthalein, (3) cyclopiazonic acid, (4) BTP2, (5) adenophostin, (6) ATP, (7) inositol triphosphate, (8) A23187, (9) 2-aminoethoxydiphenylborane (2-APB), (10) diphenylfuranhydantoin, (11), (12) caffeine, (13) diethylstibestrol, (14) resveratrol; (15) lansoprasole, (16) roflumilast, (17) teriflunomide. 
Nitric oxide displays a dual role in apoptosis regulation; low concentrations protect cells, whereas excessive levels cause apoptosis (Mori 2007). In retrospect, it is of interest to note that the cGMP-based molecular similarity of tumour modulating structures (Fig. 1) is associated with apoptosis; DMBA, MNU and PMA induce apoptosis (Table 1). Apoptotic and anti-apoptotic actions have been observed for gallic acid, genistein, silibinin and nordihydroguaiaretic acid, whereas folic acid is anti-apoptotic.

\section{$\mathrm{Ca}^{2+}$ store modulators}

Thapsigargin (Fig. 5) (1) and cyclopiazonic acid (3), inhibitors of ER Ca ${ }^{2+}$ ATPase and release agents of the $\mathrm{Ca}^{2+}$ store, provide similar fits to the guanine and ribose rings of cGMP. This molecular similarity within the structures of thapsigargin, cyclopiazonic acid and cGMP is also functionally relevant. Cell death and apoptosis are associated with sustained increases in cGMP and cytosolic $\mathrm{Ca}^{2+}$ (Yoshida et al. 2006; Sharma and Rohrer 2007; Nimmervoll et al. 2009). cGMP inhibits the actions of cyclopiazonic acid and thapsigargin on SOCE; particulate and soluble guanylyl cyclases serve distinct regulatory roles in this process (Kwan et al. 2000; Zolle et al. 2000). Estradiol and genistein attenuate apoptosis induced by thapsigargin in primary cortical neurons (Linford and Dorsa 2002).

The nucleotide fitting points of IP3 (7) and the IP3R agonists adenophostin (5) and ATP (6) focus on the nucleotide ribose ring. The aforementioned compounds reveal a similar distribution of oxygen-rich groups in relation to the structure of cGMP. The phosphorylated pyranose ring of adenophostin, the triphosphate chain of ATP, and carbonyl residues of thapsigargin and cyclopiazonic acid enclose the dioxaphosphinin ring of cGMP. This distribution of chemical groups is absent in the thapsigargin inhibitors phenolphthalein (2) and BTP2 (4). The dioxaphosphinin ring is also relevant to the fits of calcium ionophore A23187 (8), SOCE channel inhibitors 2-APB (9) and diphenylfuranhydantoin (10), and caffeine. Caffeine (11 and 12) provides at least 2 fits to the cyclic nucleotide structure. Template 11 represents a potential blocking action of caffeine on the dioxaphosphinin ring targeted by IP3 agonists. In addition to inhibiting IP3 receptors, caffeine and 2-APB deplete the $\mathrm{Ca}^{2+}$ store in a similar manner to thapsigargin (Saleem et al. 2014; Huang et al. 2017). In mouse smooth muscle cells, cGMP abolishes a sustained non-selective cation current activated by caffeine following calcium store depletion (Wayman et al. 1996).

Compounds with a stilbene pharmacophore, notably diethylstilbestrol (13), inhibit thrombin-induced $\mathrm{Ca}^{2+}$ release from platelet ER and thapsigargin-induced $\mathrm{Ca}^{2+}$ influx (Dobrydneva et al. 2003). Blockage of IP3-sensitive $\mathrm{Ca}^{2+}$ release and SOCE is attributed to the alkyl side-chains of diethylstilbestrol as genistein and resveratrol, structures without these substituents, only inhibit platelet $\mathrm{Ca}^{2+}$ influx (Dobrydneva et al. 2003, 2010). Alkyl side-chains cannot be used as nucleotide fitting points for the resveratrol structure (14). Aromatic rings within the structure of 2-APB (9) replace the carbonyl and phosphate groups of IP3 agonists, giving the antagonist less potent activity in regard to SOCE (Rahman and Rahman 2017). The nucleotide fits of more recently developed inhibitors, lansoprazole, roflumilast and teriflunomide (15-17) (Rahman and Rahman 2017) impact the nucleotide dioxaphosphinin ring with cyclopropane or trifluoride residues. Aspirin (Fig. 4, (14)) and salicylate may also inhibit tumour cell growth by targeting SOCE (Villalobos et al. 2017).

Although the $\mathrm{Ca}^{2+}$ modulating agents listed in Table 1 have a dual action, in contrast to resveratrol the protective actions of thapsigargin and cyclopiazonic acid involve transcription. Resveratrol enhances palmitate-induced ER stress and apoptosis in some cancer cell lines but attenuates apoptosis induced by high levels of glucose and palmitate in cardiac myoblast cells (Rojas et al. 2014; Xu et al. 2018). Estradiol blocks resveratrol-induced apoptosis in MCF-7 breast cancer cells (Zhang et al. 2004). Cyclopiazonic acid increases apoptosis in insulin-secreting cells (Zhou et al. 1998). Apoptosis in cancer cell lines is promoted by diethylstilbestrol, A23187, teriflunomide, lanzoprazole and caffeine (Robertson et al. 1996; Kajitani et al. 2007; Hail et al. 2012; Zhang et al. 2014; Liu et al. 2017). The IP3 receptor mediates the apoptotic action of sulforaphane (Hudecova et al. 2016). Goodness of fit values of the structures given in Figure 5 are less than $0.16 \AA$ (interatomic distance) and $0.0311 \AA$ (RMS).

The capacity of compounds to cause apoptosis and also provide protection against the process generates a confusing picture. The majority of these data relate to cell culture studies which may have methodological weaknesses: the use of pharmacological rather than physiological levels of compounds; the dual and concentration dependent actions of agents such as NO and ROS; culture systems deficient in sterol, steroid and nucleotide compounds that have the potential to change test outcomes. This difficulty in replicating the tissue environment is imposed on the natural differences in signal transduction pathways operating in various cell types. Imbalances in cyclic nucleotide cross-talk signaling networks initiate pathogenesis (Zhao et al. 2017). Effector proteins regulated by cGMP and cAMP show little selectivity at some cyclic nucleotide binding domains; selectivity requires the differential recognition of amino and carbonyl groups at adenine C6, and guanine C6 and C2 (Campbell et al. 2016). Compounds with the capacity to displace or substitute cyclic nucleotides from their receptors are potential disruptors of cell physiology.

The study findings explain how initiators/modulators of tumourigenesis, apoptosis and ion channel activity may 
disrupt the regulation of cell function by cyclic nucleotides. Although the investigated compounds vary in molecular size and chemical diversity, their relative molecular similarity to cyclic nucleotide structure is a unifying characteristic. Some endogenous structures (dexamethasone, testosterone, PgI2) relate structurally to the complete nucleotide axis, whereas other natural (vitamins A and D) and pharmaceutical (methotrexate, cytosine arabinoside) compounds do so partly. Compounds modulating $\mathrm{Ca}^{2+}[\mathrm{i}]$ via IP3 channels and SOCE demonstrate structural characteristics that relate to the nucleotide dioxaphosphinin ring. Compounds with a record of protection against apoptosis (folic acid, vitamin E, a-lipoic acid, phytic acid) provide non-specific fits to cyclic nucleotide dioxaphosphinin rings, although this type of fit is also given by apoptosis-inducing glucose-6-phosphate and ceramide (C6) structures. Molecular similarity within smaller structures (arsenic trioxide, dichlorvos) is limited to the terminal region of the cyclised ring, implicating this nucleotide moiety as one relevant to the modulation of ROS and oxidative stress.

In summary, this study provides novel data in respect of the molecular structures of compounds with established transformative and protective actions on cells, and supporting evidence for the role of cyclic nucleotides in determining the health of cells.

Molecular similarity within the compound structures is indicative of the critical role of cyclic nucleotide binding domains in the physiologic processes of tumourigenesis and apoptosis. Nucleotides and steroid hormones represent a first line of chemical defence against initiators/modulators of carcinogenesis and apoptosis, rendering cells susceptible to imbalances.

\section{References}

Abel EL, Angel JM, Kiguchi K, DiGiovanni J (2009): Multi-stage chemical carcinogenesis in mouse skin: Fundamentals and applications. Nat. Protoc. 4, 1350-1362 https://doi.org/10.1038/nprot.2009.120

Abudoureyimu A, Muhemaitibake A (2017): Arsenic trioxide regulates gastric cancer cell apoptosis by mediating cAMP. Eur. Rev. Med. Pharm. Sci. 21, 612-617

Agudo-Lopez A, Miguel BG, Fernadez I, Martinez AM (2011): Role of protein kinase $\mathrm{C}$ and mitochondrial permeability transition pore in the neuroprotective effect of ceramide in ischemiainduced cell death. FEBS Lett. 58, 99-103 https://doi.org/10.1016/j.febslet.2010.11.015

AlBasher G, AlKahtane AA, Alarifi S, Ali D, Alessia MS, Almeer RS, Almeer RS. Abdel-Daim, MM, Al-Sultan NK, Al-Qahtani AA, Ali H, Alkahtani S (2019): Methotrexate-induced apoptosis in human ovarian adenocarcinoma SKOV-3 cells via ROSmediated bax/bcl-2-cyt-c release cascading. Onco. Targets Ther. 12, 21-30 https://doi.org/10.2147/OTT.S178510
Alfonso LF, Srivenugopal KS, Arumugam TV, Abbruscato TJ, Weidanz, JA, Bhat GJ (2009): Aspirin inhibits camptothecininduced p21ClP1 levels and potentiates apoptosis in human breast cancer cells. Int. J. Oncol. 34, 597-608 https://doi.org/10.3892/ijo_00000185

Baumgartner M, Sturian S, Roth E, Wessner B, Bachleitner-Hofmann, T (2004): Enhancement of arsenic trioxide-mediated apoptosis using docosahexaenoic acid in arsenic trioxideresistant solid tumor cells. Int. J. Cancer 112, 707-712 https://doi.org/10.1002/ijc.20462

Bazan-Perkins B (2012): cGMP reduces the sarcoplasmic reticulum $\mathrm{Ca} 2+$ loading in airway smooth muscle cells: a putative mechanism in the regulation of Ca2+ by cGMP. J. Muscle Res. Cell Motil. 32, 375-382 https://doi.org/10.1007/s10974-011-9266-5

Benzer F, Kandemir FM, Ozkaraca M, Kucukler S, Caglayan C (2018): Curcumin ameliorates doxorubicin-induced cardiotoxicity by abrogation of inflammation, apoptosis, oxidative DNA damage and protein oxidation in rats. J. Biochem. Mol. Toxicol. 32, doi: $10.1002 /$ jbt.22030 https://doi.org/10.1002/jbt.22030

Bester AC, Roniger M, Oren YS, Im MM, Sarni D, Chaoat M, Bensimon A, Zamir, G, Shewach DS, Kerem B (2011): Nucleotide deficiency promotes genomic instability in early stages of cancer development. Cell 145, 435-446 https://doi.org/10.1016/j.cell.2011.03.044

Blomhoff HK (2004): Vitamin A regulates proliferation and apoptosis of human T-and B- cells. Biochem. Soc. Trans. 32, 982-984. https://doi.org/10.1042/BST0320982

Bonavida B, Garban H (2015): Nitric oxide-mediated sensitization of resistant tumor cells to apoptosis by chemo-immunotherapeutics. Redox Biol. 6, 486-494 https://doi.org/10.1016/j.redox.2015.08.013

Bonavita F, Stefanelli C, Giordano E, Columbaro M, Facchini A, Bonafe F, Caldarera CM, Guamieri C (2003): H9c2 cardiac myoblasts undergo apoptosis in a model of ischemia consisting of serum deprivation and hypoxia: inhibition by PMA. FEBS Lett. 536, 85-91 https://doi.org/10.1016/S0014-5793(03)00029-2

Brunetti M, Mascetra,N, Manarini S, Martelli N, Cerletti C, Musiani P, Alello FB, Evangelista V (2002): Inhibition of cGMP-dependent protein kinases potently decreases neutrophil spontaneous apoptosis. Biochem. Biophys. Res. Commun. 297, 498-501 https://doi.org/10.1016/S0006-291X(02)02246-5

Cai J, Cao S, Chen J, Yan F, Chen G, Dai Y (2015): Progesterone alleviates brain injury via reducing apoptosis and oxidative stress in a rat experimental subarachnoid hemorrhage model. Neurosci. Lett. 600, 238-243

https://doi.org/10.1016/j.neulet.2015.06.023

Campbell JC, Kim JJ, Li KY, Huang GY, Reger AS, Matsuda S, Sankaran B, Link TM, Yuasa K, Ladbury, JE, Casteel DE, Kim C (2016): Structural basis of cyclic nucleotide selectivity in cGMPdependent protein kinase II. J. Biol. Chem. 291, 5623-5633 https://doi.org/10.1074/jbc.M115.691303

Capper CP, Rae JM, Auchus RJ (2016): The metabolism, analysis, and targeting of steroid hormones in breast and prostate cancer. Horm. Cancer 7, 149-164 
https://doi.org/10.1007/s12672-016-0259-0

Chandrasekhar Y, Phani Kumar G, Ramya EM, Anilakumar KR (2018): Gallic acid protects 6-OHDA induced neurotoxicity by attenuating oxidative stress in human dopaminergic cell line. Neurochem. Res. 43, 1150-1160 https://doi.org/10.1007/s11064-018-2530-y

Chen C, Jiang X, Lai Y, Lui Y, Zhang Z (2015): Resveratrol protects against arsenic trioxide-induced oxidative damage through maintenance of glutathione homeostasis and inhibition of apoptotic progression. Environ. Mol. Mutagen 56, 33-46 https://doi.org/10.1002/em.21919

Chen WP, Chi TC, Chuang LM, Su MJ (2007): Resveratrol enhances insulin secretion by blocking $\mathrm{K}(\mathrm{ATP})$ and $\mathrm{K}(\mathrm{V})$ channels of beta cells. Eur. J. Pharmacol. 568, 269-277 https://doi.org/10.1016/j.ejphar.2007.04.062

Choi YH (2018): ROS-mediated activation of AMPK plays a critical role in sulforaphane-induced apoptosis and mitotic arrest in AGS human gastric cancer cells. Gen. Physiol. Biophys. 37, 129-140 https://doi.org/10.4149/gpb_2017026

Culver CA, Michalowski SM, Maia RC, Laster SM (2005): The anti-apoptotic effects of nordihydroguaiaretic acid: inhibition of cPLA(2) activation during TNF-induced apoptosis arises from inhibition of calcium signaling. Life Sci. 77, 2457-2470

https://doi.org/10.1016/j.lfs.2005.03.023

Da Silva EO, Gerez JR, Hohmann MSN, Verri WA, Bracarense APFRL (2019): Phytic acid decreases oxidative stress and intestinal lesions induced by fumonisin B1 and deoxynivalenol in intestinal explants of pigs. Toxins $\mathbf{1 1}$ https://doi.org/10.3390/toxins11010018

Das S, Joardar S, Manna P, Dua TK, Bhattacharjee N. Khanra R, Bhowmick,S, Kalita J, Saha A, Ray S, De Feo,V, Dewanjee $S$ (2018): Carnosic acid, a natural diterpene, attenuates arsenicinduced hepatotoxicity via reducing oxidative stress, MAPK activation, and apoptotic cell death pathway. Oxid. Med. Cell Longev.

https://doi.org/10.1155/2018/1421438

de Arriba G, de Homedo JP, Rubio SR, Fernandez MC, Martinez SB, Camarero MM, Cid TP (2009): Vitamin E protects against the mitochondrial damage caused by cyclosporine A in LLC-PK1 cells. Toxicol. Appl. Pharmacol. 239, 241-250 https://doi.org/10.1016/j.taap.2009.05.028

Deng S, Dai G, Chen S, Zhigang N, Zhou J, Hongsong F, Peng H (2019): Dexamethasone induces osteoblast apoptosis through ROS-P13K/AKT/GSK3 $\beta$ signaling pathway. Biomed. Pharmacol. Ther. 11, 602-608 https://doi.org/10.1016/j.biopha.2018.11.103

Derakhshan A, Chen Z, van Waes C (2017): Therapeutic smallmolecules target inhibitor of apoptosis proteins in cancers with deregulation of extrinsic and intrinsic cell death pathways. Clin. Cancer Res. 23, 1379-1387 https://doi.org/10.1158/1078-0432.CCR-16-2172

Dobrydneva Y, Williams RL, Katzenellenbogen JA, Ratz, PH, Blackmore PF (2003): Diethylstilbestrol and tetrahydrochrysenes are calcium channel blockers in human platelets: relationship to the stilbene pharmacophore. Thromb. Res. 110, 23-31 https://doi.org/10.1016/S0049-3848(03)00110-5
Dobrydneva Y, Williams RL, Blackmore PF (2010): Diethylstilbestrol and other nonsteroidal estrogens: novel class of store-operated calcium channel modulators. J. Cardiovasc. Pharmacol. 55, 522-530 https://doi.org/10.1097/FJC.0b013e3181d64b33

Eftekhar-Vaghefi S, Esmaeili-Mahani S, Elyasi L, Abbasnejad, M (2015): Involvement of $\mathrm{Mu}$ opioid receptor signaling in the protective effect of opioid against 6-hydroxydopamine-induced SH-SY5Y human neuroblastoma cells apoptosis. Basic Clin. Neurosci. 6, 171-178

Emoto Y, Yoshizawa,Y, Kinoshita Y, Yuki M, Yuri T, Tsubura A (2016): Green tea extract attenuates MNU-induced photoreceptor cell apoptosis via suppression of heme oxyenase- 1 . J. Toxicol. Pathol. 29, 61-65 https://doi.org/10.1293/tox.2015-0052

Erboga M, Aktas C, Erboga ZF, Donmez YB, Gurel A (2015): Quercetin ameliorates methotrexate-induced renal damage, apoptosis and oxidative stress in rats. Ren. Fail. 37, 1492-1497 https://doi.org/10.3109/0886022X.2015.1074521

Fallahian F, Karami-Tehrani F, Salami S, Aghaei M (2011): Cyclic GMP induced apoptosis via protein kinase G in oestrogen receptor-positive and -negative breast cancer cell lines. FEBS J. 278, 3360-3369 https://doi.org/10.1111/j.1742-4658.2011.08260.x

Fajardo AM. Piazzo GA, Tinsley HN (2014): The role of cyclic nucleotide signaling pathways in cancer: targets for prevention and treatment. Cancers 6, 436-458 https://doi.org/10.3390/cancers6010436

Fatemi A, Kazemi A, Kashiri M, Safa, M (2015): Elevation of cAMP levels inhibits doxorubicin-induced apoptosis in pre-B ALL NALM-6 cells through induction of BAD phosphorylation and inhibition of p53 accumulation. Int. J. Mol. Cell Med. 4, 94-102

Feldman RD, Limbird LE (2017): GPER (GPR30): A nongenomic receptor (GPCR) for steroid hormones with implications for cardiovascular disease and cancer. Annu. Rev. Pharmacol. Toxicol. 57, 567-584 https://doi.org/10.1146/annurev-pharmtox-010716-104651

Fraser M, Chan SL, Chan SS, Fiscus RR, Tsang BK (2006): Regulation of $\mathrm{p} 53$ and suppression of apoptosis by the soluble guanylyl cyclase/cGMP pathway in human ovarian cells. Oncogene 25, 2203-2212 https://doi.org/10.1038/sj.onc.1209251

Fujita H, Ogino T, Kobuchi H, Fujiwara T, Yano H, Akiyama J, Utsumi K, Sasaki J (2006): Cell-permeable cAMP analog suppresses 6-hydroxydopamine-induced apoptosis in PC12 cells through the activation of the Akt pathway. Brain Res. 1113, 10-23 https://doi.org/10.1016/j.brainres.2006.06.079

Garcia-Bermejo L, Perez C, Vilaboa NE, de Blas, E, Aller P (1998): cAMP increasing agents attenuate apoptosis by etoposide in promonocytic leukemia cells. J. Cell Sci. 111, 637-644

Ge L, Hoa NT, Wilson Z, Arismendi-Morillo G, Kong XT, Tajhya RB, Beeton C, Jadus MR (2014): Big potassium (BK) ion channels in biology, disease and possible targets for cancer immunotherapy. Int. Immunopharmacol. 22, 427-443 https://doi.org/10.1016/j.intimp.2014.06.040

Greenberg HZE, Shi J, Jahan KS, Martinucci MC, Gilbert SJ, Ho, WSV, Albert AP (2016): Stimulation of calcium-sensing re- 
ceptors induces endothelium-dependent vasorelaxations via nitric oxide production and activation of IKCa channels. Vasc. Pharmacol. 80, 75-84

https://doi.org/10.1016/j.vph.2016.01.001

Gu S, Chen S, Jiang X, Zhang Z (2016): ROS-mediated endoplasmic reticulum stress and mitochondrial dysfunction underlie apoptosis induced by resveratrol and arsenic trioxide in A549 cells. Chem. Biol. Interact. 245, 100-109 https://doi.org/10.1016/j.cbi.2016.01.005

Ha KS, Kim KM, Kwon YG, Bai SK, Nam WD, Yoo YM, Kim PK, Chung HT, Billiar TR, Kim YM (2003): Nitric oxide prevents 6-hydroxydopamine-induced apoptosis in PC12 cells through cGMP-dependent P13 kinase/Akt activation. FASEB J. 17, 1036-1047 https://doi.org/10.1096/fj.02-0738com

Ha SW, Kim YJ, Kim W, Lee CS (2009): Antitumor effects of camptothecin combined with conventional anticancer drugs on the cervical and uterine squamous cell carcinoma cell line SiHa. Korean J. Physiol. Pharmacol. 13, 115-121 https://doi.org/10.4196/kjpp.2009.13.2.115

Hail N, Chen P, Kepa, JJ, Bushman LR (2012): Evidence supporting a role for dihydroorotate dehydrogenase, bioenergetics, and p53 in selective teriflunomide-induced apoptosis in transformed versus normal human keratinocytes. Apoptosis 17, 258-268 https://doi.org/10.1007/s10495-011-0667-0

Ham J, Lim W, Bazer FW, Song G (2018): Silibinin stimulates apoptosis by inducing generation of ROS and ER stress in human choriocarcinoma cells. J. Cell Physiol. 233, 1638-1649 https://doi.org/10.1002/jcp.26069

Hambrock A, de Oliveira FCB, Hiller S, Grenz A, Ackermann S, Schulze DU, Drews G, Osswald H (2007): Resveratrol binds to the sulfonylurea receptor (SUR) and induces apoptosis in a SUR subtype-specific manner. J. Biol. Chem. 282, 3347-3356 https://doi.org/10.1074/jbc.M608216200

Hammond R, Nelson D, Gibbs RB (2011): GPR30 co-localizes with cholinergic neurons in the basal forebrain and enhances potassium-stimulated acetylcholine release in the hippocampus. Psychneuroendocrinology 36, 182-192 https://doi.org/10.1016/j.psyneuen.2010.07.007

Harding SD, Sharman JL, Faccenda E, Southan C, Pawson AJ, Ireland S, Gray AJG, Bruce L, Alexander SPH, Anderton S, et al. (2018): The IUPHAR/BPS Guide to Pharmacology in 2018: updates and expansion to encompass the new guide to Immunopharmacology Nucl. Acids Res. 46, D1091-D1106 https://doi.org/10.1093/nar/gkx1121

Harriman JF, Liu XL, AleoMD, Machaca K, Schnellmann RG (2002): Endoplasmic reticulum $\mathrm{Ca}(2+)$ signaling and calpains mediate renal cell death. Cell Death Differ. 9, 734-741 https://doi.org/10.1038/sj.cdd.4401029

Hernandez-Damian J, Anderica-Romero AC, Pedraza-Chaverri J (2014): Paradoxical cellular effects and biological role of the multifaceted compound nordihydroguaiaretic acid. Arch. Pharm. 347, 685-697 https://doi.org/10.1002/ardp.201400159

Hou H, Zhao Z, Machuki JO (2018): Estrogen deficiency compromised the $\beta 2 \mathrm{AR}-\mathrm{Gs} / \mathrm{Gi}$ coupling: implications for arrhythmia and cardiac injury. Pflugers Arch. 470, 559-570 https://doi.org/10.1007/s00424-017-2098-4
Hsu CH, Ho YS, Lai CS, Hsieh SC, Chen LH, Lin E, Ho CT, Pan MH (2013): Hexahydro- $\beta$-acids potently inhibit $12-\mathrm{O}-$ tetradecanoylphorbol 13-acetate-induced skin inflammation and tumor promotion in mice. J. Agric. Food Chem. 61, 11541-11549 https://doi.org/10.1021/jf403560r

Hsu WL, Tsai MH, Lin MW, Chiu YC, Lu JH, Chang CH, Yu HS, Yoshioka T (2012): Differential effects of arsenic on calcium signaling in primary keratinocytes and malignant (HSC-1) cells. Cell Calcium 52, 161-169 https://doi.org/10.1016/j.ceca.2012.05.007

Huang W, Cane MC, Mukherjee R, Szatmary P, Zhang X, Elliott V, Ouyang Y, Chvanov M, Latawiec D, Wen Li, et al. (2017): Caffeine protects against experimental acute pancreatitis by inhibition of inositol 1,4,5-triphosphate receptor-mediated Ca2 release. Gut 66, 301-313 https://doi.org/10.1136/gutjnl-2015-309363

Hudecova S, Markova J, Simko V, Csaderova L, Stracina T, Sirova M, Fojtu M, Svastova E, Gronesova, P, Pastorek M, et al. (2016): Sulphoraphane-induced apoptosis involves the type 1 IP3 receptor. Oncotarget 7, 61403-61418 https://doi.org/10.18632/oncotarget.8968

Insel PA, Zhang L, Murray F, Yokouchi H, Zambon AC (2012): Cyclic AMP is both a pro-apoptotic and anti-apoptotic second messenger. Acta. Physiol. (Oxf) 204, 277-287 https://doi.org/10.1111/j.1748-1716.2011.02273.x

Ishikawa T, Kaneko Y, Sugino F, Nakayama K (2003) Two distinct effects of cGMP on cytosolic Ca2+ concentration of rat pancreatic $\beta$-cells. J. Pharmacol. Sci. 91, 41-46 https://doi.org/10.1254/jphs.91.41

Itsumi M, Shiota M, Yokomizo A, Takeuchi A, Kashiwagi E, Dejima T, Inokuchi J, Tatsugami K, Uchiumi T, Naito S (2014.): PMA induces androgen receptor downregulation and cellular apoptosis in prostate cancer cells. J. Mol. Endocrinol. 53, 31-41 https://doi.org/10.1530/JME-13-0303

Jehle J, Schweizer PA, Katus HA, Thomas D (2011): Novel roles for hERG K+ channels in cell proliferation and apoptosis. Cell Death Dis. 2 https://doi.org/10.1038/cddis.2011.77

Jaisin Y, Thampithak A, Meesarapee B, Ratanachamnong P, Suksamram A, Phivthong-Ngam L, Phumala-Morales N, Chongthammakun S, Govitrapong P, Sanvarinda Y (2011): Curcumin 1 protects the dopaminergic cell line SH-SY5Y from 6-hydroxydopamine-induced neurotoxicity through attenuation of p53-mediated apoptosis. Neurosci. Lett. 489, 192-196 https://doi.org/10.1016/j.neulet.2010.12.014

Jian Z, Tang L, Yi X, Liu B, Zhang Q, Zhu G, Wang G, Gao T, Li C (2016): Aspirin induces Nrf2-mediated transcriptional activation of haem oxygenase- 1 in protection of human melanocytes from H202-induced oxidative stress. J. Cell Mol. Med. 20, $1307-1318$ https://doi.org/10.1111/jcmm.12812

Kajitani N, Kobuchi H, Fujita H, Yano H, Fujiwara T, Yasuda T, Utsumi K (2007): Mechanism of A23187-induced apoptosis in HL-60 cells: dependency on mitochondrial permeability transition but not on NADPH oxidase. Biosci. Biotechnol. Biochem. 71, 2701-2711 https://doi.org/10.1271/bbb.70304 
Kang J, Jia, Z, Ping Y, Liu Z, Yan X, Xing G, Yan W (2018): Testosterone alleviates mitochondrial ROS accumulation and mitochondria-mediated apoptosis in the gastric mucosa of orchiectomized rats. Arch Biochem. Biophys. 649, 53-59 https://doi.org/10.1016/j.abb.2018.05.002

Kang KS, Wang P, Yamabe N, Fukui M, Jay T, Zhu BT (2010): Docosahexaenoic acid induces apoptosis in MCF-7 cells in vitro and in vivo via reactive oxygen species formation and caspase 8 activation. PLoS One 5, e10296 https://doi.org/10.1371/journal.pone.0010296

Kang YJ, Kim IY, Kim EH, Yoon MJ, Kim SU, Kwon TK, Choi KS (2011): Paxilline enhances TRAIL-mediated apoptosis of glioma cells via modulation of c-FLIP, survivIn and DR5. Exp. Mol. Med. 43, 24-34 https://doi.org/10.3858/emm.2011.43.1.003

Kanno S, Shouji A, Hirata R, Asou K, Ishikawa M (2004): Effects of naringin on cytosine arabinoside (Ara-C)-induced cytotoxicity and apoptosis in P388 cells. Life Sci. 75, 353-365 https://doi.org/10.1016/j.lfs.2003.12.019

Kastrati I, Edirisinghe PD, Wijewickrama GT, Thatcher GRJ (2010): Estrogen-induced apoptosis of breast epithelial cell is blocked by NO/cGMP and mediated by extranuclear estrogen receptors. Endocrinology 151, 5602-5616 https://doi.org/10.1210/en.2010-0378

Ketley NJ, Allen PD, Kelsey SM, Newland AC (1997): Modulation of idarubicin-induced apoptosis in human acute myeloid leukemia blasts by all-trans-retinoic acid, 1,25(OH)2 vitamin D3 and granulocyte-macrophage colony-stimulating factor. Blood 90, 4578-4587 https://doi.org/10.1182/blood.V90.11.4578

Khafaga AF, El-Sayed YS (2018): All-trans-retinoic acid ameliorates doxorubicin-induced cardiotoxicity: in vivo potential involvement of oxidative stress, inflammation, and apoptosis via caspase- 3 and p53 down-expression. Naunyn Schmiedebergs Arch. Pharmacol. 391, 59-70 https://doi.org/10.1007/s00210-017-1437-5

Kim JE, Song SE, Kim YW, Kim JY, Park SC, Park YK, Baek SH, Lee IK, Park SY (2010): Adiponectin inhibits palmitate-induced apoptosis through suppression of reactive oxygen species in endothelial cells: involvement of cAMP/protein kinase A and AMP-activated protein kinase. J. Endocrinol. 207, 35-44 https://doi.org/10.1677/JOE-10-0093

Kim YM, Choi BM, Kim YS, Kwon YG, Kibbe MR, Billiar TM, Tzeng E (2008): Protective effect of p53 in vascular smooth muscle cells against nitric oxide-induced apoptosis is mediated by up-regulation of heme oxygenase- 2 . BMB rep. 41, 164-169 https://doi.org/10.5483/BMBRep.2008.41.2.164

Klamt F, Dal-Pizzol F, Gelain DP, Dalmolin RS, Birnfeld de Oliveira R, Bastiani M, Horn F, Fonseca Moreira JC (2008): Vitamin A treatment induces apoptosis through an oxidant-dependent activation of the mitochondrial pathway. Cell Biol. Int. 32, 100-106 https://doi.org/10.1016/j.cellbi.2007.08.018

Koul A, Kaur N, Chugh NA (2018): Folic acid modulates DMBA/ TPA-induced changes in skin of mice: a study relevant to carcinogenesis. J. Diet. Suppl. 15, 72-87

https://doi.org/10.1080/19390211.2017.1322659
Koren R, Hadari-Naor I, Zuck, E, Rotem C, Lieberman, UA, Ravid A (2001): Vitamin D is a prooxidant in breast cancer cells. Cancer Res. 61, 1439-1444

Kow LM, Pfaff DW (2018): Can distinctly different estrogen actions share a common mechanistic step. Horm. Behav. 104, 156-164 https://doi.org/10.1016/j.yhbeh.2018.02.008

Kumar N, Gupta S, Dabral S, Singh S, Sehrawat S (2017): Role of exchange protein directly activated by cAMP (EPAC1) in breast cancer cell migration and apoptosis. Mol. Cell. Biochem. 430, 115-125 https://doi.org/10.1007/s11010-017-2959-3

Kwan HY, Huang Y, Yao, X (2000): Store-operated calcium entry in vascular endothelial cells is inhibited by cGMP via a protein kinase G-dependent mechanism. J. Biol. Chem. 275, 6758-6763 https://doi.org/10.1074/jbc.275.10.6758

Kwon G, Pappan KL, Marshall CA, Schaffer JE, McDaniel ML (2004): cAMP dose-dependently prevents palmitate-induced apoptosis by both kinase A-and cAMP-guanine nucleotide exchange factor-dependent pathways in beta-cells. J. Biol. Chem. 279, 8938-8945 https://doi.org/10.1074/jbc.M310330200

Lee JW, Choi AH, Ham M, Kim JW, Choe SS, Lee GY, Yoon KH, Kim JB (2011): G6PD up-regulation promotes pancreatic betacell dysfunction. Endocrinology 152, 793-803 https://doi.org/10.1210/en.2010-0606

Lee WJ, Hsiao M, Chang JL, Yang SF, Tseng TH, Cheng CW, Chow JM, Lin KH, Lin YW, Liu CC, Lee LM, Chien MH (2015): Quercetin induces mitochondrial-derived apoptosis via reactive oxygen species-mediated ERK activation in HL-60 leukemia cells and xenograft. Arch. Toxicol. 89, 1103-1117 https://doi.org/10.1007/s00204-014-1300-0

Lee WY, Park CJ, Shin TJ (2009): Only tetracaine and not other local anaesthetics induce apoptosis in rat cortical astrocytes. Br. J. Anaesth. 103, 719-725 https://doi.org/10.1093/bja/aep237

Lee YK, Park OJ (2013): Soybean isoflavone genistein regulates apoptosis through NF-kB dependent and independent pathways. Exp. Toxicol. Pathol. 65, 1-6 https://doi.org/10.1016/j.etp.2011.05.001

Leskiewicz M, Jantas D, Budziszewska B, Lason W (2008) Excitatory neurosteroids attenuate apoptotic and excitotoxic cell death in primary cortical neurons. J. Physiol. Pharmacol. 59, 457-475

Levin ER, Hammes SR (2016): Nuclear receptors outside the nucleus: extranuclear signaling by steroid receptors. Nat. Rev. Mol. Cell. Biol. 17, 783-797 https://doi.org/10.1038/nrm.2016.122

Li RC, Cindrova-Davies T, Skepper JN, Sellers LA (2004): Prostacyclin induces apoptosis of vascular smooth muscle cells by a cAMP-mediated inhibition of extracellular signal-regulated kinase activity and can counteract the mitogenic activity of endothelin-1 or basic fibroblast growth factor. Circ. Res. 94, 759-767

https://doi.org/10.1161/01.RES.0000121568.40692.97

Lim JY, Kim D, Kim BR, Jun JS, Yeom JS, Park JS, Seo JH, Park CH, Woo HO, Youn HS, et al. (2016): Vitamin C induces apoptosis in AGS cells via production of ROS of mitochondria. Oncol. Lett. 12, 4270-4276 https://doi.org/10.3892/ol.2016.5212 
Lin ML, Chen SS (2017): Activation of casein kinase II by gallic acid induces BIK-BAX/BAK- mediated ER Ca++-ROS-dependent apoptosis of human oral cancer cells. Front. Physiol. 8 https://doi.org/10.3389/fphys.2017.00761

Linford NJ, Dorsa DM (2002): 17beta-estradiol and the phytoestrogen genistein attenuate neuronal apoptosis induced by the endoplasmic reticulum calcium-ATPase inhibitor thapsigargin. Steroids 67, 1029-1040 https://doi.org/10.1016/S0039-128X(02)00062-4

Liu H, Zhou Y, Tang L (2017): Caffeine induces sustained apoptosis of human gastric cancer cells by activating the caspase-9/ caspase-3 signaling pathway. Mol. Med. Rep. 16, 2445-2452 https://doi.org/10.3892/mmr.2017.6894

Lopes RA, Neves KB, Pestana CR, Queiroz AL, Zanotto CZ, Chignalia AZ, Valim YM, Silveira LR, Curti C, Tostes RC (2014): Testosterone induces apoptosis in vascular smooth muscle cells via extrinsic apoptotic pathway with mitochondria-generated reactive oxygen species involvement. Am. J. Physiol. Heart Circ. Physiol. 306, H1485-1494

https://doi.org/10.1152/ajpheart.00809.2013

Lu T, Zhou D, Gao P, Si L, Xu, Q (2018): Resveratrol attenuates high glucose-induced endothelial cell apoptosis via mediation of store-operated calcium entry. Mol. Cell Biochem. 442, $73-80$ https://doi.org/10.1007/s11010-017-3194-7

Luo J, Wang A, Zhen W, Wang Y, Si H, Jia Z, Alkhalidy H, Cheng Z, Gilbert E, Xu B, Liu D (2018): Phytonutrient genistein is a survival factor for pancreatic $\beta$-cells via GPR30-mediated mechanism. J. Nutr. Biochem. 58, 59-70 https://doi.org/10.1016/j.jnutbio.2018.04.018

Lyons NM, Woods JA, O'Brien NM (2001): alpha-Tocopherol, but not gamma-tocopherol inhibits 7 beta-hydroxycholesterolinduced apoptosis in human U937 cells. Free Radic. Res. 35, 329-339 https://doi.org/10.1080/10715760100300861

Ma H, Butler MR., Thapa A, Belcher J, Yang F, Baehr W, Biel M, Michalakis S, Ding XQ (2015): cGMP/protein kinase G signaling suppresses inositol 1,4,5-triphosphate receptor phosphorylation and promotes endoplasmic reticulum stress in photoreceptors of cyclic nucleotide-gated channel-deficient mice. J. Biol. Chem. 290, 20880-20892 https://doi.org/10.1074/jbc.M115.641159

Machuki JO, Zhang HY, Harding SE, Sun H (2018): Molecular pathways of oestrogen receptors and $\beta$-adrenergic receptors in cardiac cells: Recognition of their similarities, interactions and therapeutic value. Acta. Physiol. (Oxf) 222 https://doi.org/10.1111/apha.12978

Maqoud F, Curci A, Scala R, Pannunzio A, Campanella F, Coluccia M, Passantino G, Zizzo N, Tricarico D (2018): Cell cycle regulation by $\mathrm{Ca} 2+$-activated $\mathrm{K}+(\mathrm{BK})$ channels modulators in SH-SY5Y neuroblastoma cells. Int. J. Mol. Sci. 19, 2442 https://doi.org/10.3390/ijms19082442

Marathe N, Rangaswami H, Zhuang S, Boss GR, Pilz RB (2012): Pro-survival effects of $17 \beta$-estradiol on osteocytes are mediated by nitric oxide/cGMP via differential actions of cGMP-dependent protein kinases 1 and 11. J. Biol. Chem. 287, 978-988

https://doi.org/10.1074/jbc.M111.294959
Marwarha G, Raza S, Hammer K, Ghribi O (2017): 27-hydroxycholesterol: A novel player in molecular carcinogenesis of breast and prostate cancer. Chem. Phys. Lipids 207, 108-126 https://doi.org/10.1016/j.chemphyslip.2017.05.012

Matsunaga T, Kotamraju S., Kalivendi SV, Dhanasekaran A, Joseph J, Kalyanaraman B (2004): Ceramide-induced intracellular oxidant formation, iron signaling, and apoptosis in endothelial cells: protective role of endogenous nitric oxide. J. Biol. Chem. 279, 28614-28624

https://doi.org/10.1074/jbc.M400977200

McFerrin MB, Turner K., Cuddapah VA, Sontheimer H (2012): Differential role of IK and BK potassium channels as mediators of intrinsic and extrinsic apoptotic cell death. Am. J. Cell Physiol. 15, C1070-C1078 https://doi.org/10.1152/ajpcell.00040.2012

Messina E, Gazzaniga P, Micheli, V, Guaglianone MR, Barbato S, Morrone S, Frati, L, Agliano AM, Giacomello A (2004): Guanine nucleotide depletion triggers cell cycle arrest and apoptosis in human neuroblastoma cell lines. Int. J. Cancer 108, 812-817 https://doi.org/10.1002/ijc.11642

Michel L, Dupuy A, Jean-Louis F, Sors A, Poupon J, Viguier M, Musette P, Dubertret L, Degos L, Dombret H, Bachelez H (2003) Arsenic trioxide induces apoptosis of cutaneous T cell lymphoma cells: evidence for a partially caspase-independent pathway and potentiation by ascorbic acid (vitamin C). J. Invest. Dermatol. 121, 881-893 https://doi.org/10.1046/j.1523-1747.2003.12479.x

Miura Y, Murata Y, Utsumi K, Takahata K, Tada M, Otsuki, T (2005): The inhibitory effect of dibutyryl cyclic AMP on docosahexaenoic acid-induced apoptosis in HL-60cells through activation of the phosphatidylinositol-3-kinase pathway. Environ. Health Prev. Med. 10, 184-189

https://doi.org/10.1265/ehpm.10.184

Mori M (2007): Regulation of nitric oxide synthesis and apoptosis by arginase and arginine recycling. J. Nutr. 137, 1616S-1620S https://doi.org/10.1093/jn/137.6.1616S

Mortezaee K, Salehi E, Mirtavoos-mahyari, H, Motevaseli E, Najafi M, Farhood B, Rosengren RJ, Sahebkar A (2019): Mechanisms of apoptosis modulation by curcumin: implications for cancer therapy. J. Cell. Physiol. 234, 12537-12550

https://doi.org/10.1002/jcp.28122

Mourlevat S, Troadec JD, Ruberg M, Michel PP (2003): Prevention of dopaminergic neuronal death by cyclic AMP in mixed neuronal/glial mesencephalic cultures requires the repression of presumptive astrocytes. Mol. Pharmacol. 64, 578-586 https://doi.org/10.1124/mol.64.3.578

Naderi S, Blomhoff HK (2008): Activation of cAMP signaling enhances Fas-mediated apoptosis and activation-induced cell death through potentiation of caspase 8 activation. Hum. Immunol. 69, 833-836 https://doi.org/10.1016/j.humimm.2008.09.005

Nimmervoll B, Svoboda N, Sacha B, Kerschbaum HH (2009): Sustained elevation of cyclic guanosine monophosphate induces apoptosis in microglia. Brain. Res. Bull. 80, 428-432 https://doi.org/10.1016/j.brainresbull.2009.08.002

Nguyen H, Syed V (2011): Progesterone inhibits growth and induces apoptosis in cancer cells through modulation of reactive oxygen species. Gynecol. Endocrinol. 27, 830-836 
https://doi.org/10.3109/09513590.2010.538100

Octavia Y, Kararigas G, de Boer M, Chrifi I, Kietadisorn R, Swinnen M, Duimel H, Verheyen FK, Brandt MM, Fliegner D, et al. (2017): Folic acid reduces doxorubicin-induced cardiomyopathy by modulating endothelial nitric oxide synthetase. J. Cell Mol. Med. 21, 3277-3287 https://doi.org/10.1111/jcmm.13231

Orbo A, Hanevik M, Jaeger R, Van Heusden S, Sager G (2007): Urinary cyclic GMP after treatment of gynecological cancer. A prognostic marker of clinical outcome. Anticancer Res. 27, 2591-2596

Paterni L, Granchi C, Katzenellenbogen JA, Minutolo F (2014): Estrogen receptors alpha $(\mathrm{ER} \alpha)$ and beta $(\mathrm{ER} \beta)$ : subtype-selective ligands and clinical potential. Steroids 90, 13-29 https://doi.org/10.1016/j.steroids.2014.06.012

Patil JR, Javaprakasha GK, Kim J, Murthy KN, Chetti MB, Nam SY, Patil BS (2013): 5-Geranyloxy-7-methoxycoumarin inhibits colon cancer (SW480) cells growth by inducing apoptosis. Planta Med. 79, 219-226 https://doi.org/10.1055/s-0032-1328130

Petak I, Mihalik R, Bauer PI, Suli-Vargha H, Sebestyen A, Kopper L (1998): BCNU is a caspase-mediated inhibitor of drug-induced apoptosis. Cancer Res. 58, 614-618

Pozner RG, Negrotto S, D'Atri LP, Kotler ML, Lazzari MA, Gomez RM, Schattner M (2005): Prostacyclin prevents nitric oxideinduced megakaryocyte apoptosis. Br. J. Pharmacol. 145, 283-292 https://doi.org/10.1038/sj.bjp.0706200

Prossnitz ER, Hathaway HJ (2015): What have we learned about GPER function in physiology and disease from knockout mice? J. Steroid Biochem. Mol. Biol. 153, 114-126 https://doi.org/10.1016/j.jsbmb.2015.06.014

Qian YH, Xaio Q, Chen H, Xu J (2009): Dexamethasone inhibits camptothecin -induced apoptosis in C6-glioma via activation of Stat5/Bcl-xLpathway. Biochim. Biophys. Acta 5, 764-771 https://doi.org/10.1016/j.bbamcr.2009.01.017

Rahman S, Farooque A, Anjum S, Ansari RA, Adhikari JS, Dwarakanath BS, Raisuddin, S (2015): Norhydroguiaretic acid attenuates skin tumorigenesis in Swiss albino mice with the condition of topical co-administration of an immunosuppressant. Chem. Biol. Interact. 233, 106-114 https://doi.org/10.1016/j.cbi.2015.03.006

Rahman S, Rahman T (2017): Unveiling some FDA-approved drugs as inhibitors of the store-operated $\mathrm{Ca} 2+$ entry pathway. Sci. Rep. 7 https://doi.org/10.1038/s41598-017-13343-x

Rappaport JA, Waldman SA (2018): The guanylate cyclase C-cGMP signaling axis opposes intestinal epithelial injury and neoplasia. Front. Oncol. 8 https://doi.org/10.3389/fonc.2018.00299

Raza H, John A (2012): Implications of altered glutathione metabolism in aspirin-induced oxidative stress and mitochondrial dysfunction in HepG2 cells. PLoS One 7, e36325 https://doi.org/10.1371/journal.pone.0036325

Redza-Dutordoir M, Averill-Bates DA (2016): Activation of apoptosis signalling pathways by reactive oxygen species. Biochim. Biophys. Acta 1863, 2977-2992 https://doi.org/10.1016/j.bbamcr.2016.09.012

Riendeau V, Garenc C (2009): Effect of 27-hydroxycholesterol on survival and death of human macrophages and vascular smooth muscle cells. Free Radic. Res. 43, 1019-1028 https://doi.org/10.1080/10715760903040610

Robertson CN, Robertson KM, Padilla GM, O’Brien ET, Cook JM, Kim CS, Fine RL (1996): Induction of apoptosis by diethylstilbestrol in hormone-insensitive prostate cancer cells. J. Natl. Cancer Inst. 88, 908-917 https://doi.org/10.1093/jnci/88.13.908

Robinson DL, Nag S, Mokh SS (2016): Estrogen facilitates and the kappa and mu opioid receptors mediate antinociception produced by intrathecal (-)-pentazocine in female rats. Behav. Brain Res. 312, 163-168 https://doi.org/10.1016/j.bbr.2016.06.019

Rojas C, Pan-Castillo B, Valls, C, Pujadas, G, Garcia-Vallve S, Arola L, Mulero M (2014): Resveratrol enhances palmitate-induced ER stress and apoptosis in cancer cells. PLOS One 9, e113929 https://doi.org/10.1371/journal.pone.0113929

Ruiz LM, Bedoya G, Salazar J, Garcia de OD, Patino PJ (2002): Dexamethasone inhibits apoptosis of human neutrophils induced by reactive oxygen species. Inflammation 26, 215-222 https://doi.org/10.1023/A:1019714618068

Safa M, Mousavizadeh K, Noori S, Pourfathollah A, Zand H (2014): cAMP protects acute promelocytic leukemia cells from arsenic trioxide-induced caspase-3 activation and apoptosis. Eur. J. Pharmacol. 736, 115-123 https://doi.org/10.1016/j.ejphar.2014.04.040

Saleem H, Tovey SC, Molinski TF, Taylor CW (2014): Interactions of antagonists with subtypes of inositol 1,4,5-triphosphate (IP3) receptor. Br. J. Pharmacol. 171, 3298-3312 https://doi.org/10.1111/bph.12685

Salem IB, Boussabbeh M, Graiet I, Rhouma A, Bacha H, Essefi, SA (2016): Quercetin protects HCT116 cells from dichlorvosinduced oxidative stress and apoptosis. Cell Stress Chaperones 21, 179-186 https://doi.org/10.1007/s12192-015-0651-7

Sanchez Y, Calle C, de Blas E, Aller P (2009): Modulation of arsenic trioxide-induced apoptosis by genistein and functionally related agents in U937 human leukaemia cells. Regulation by ROS and mitogen-activated protein kinases. Chem. Biol. Interact. 182, 37-44 https://doi.org/10.1016/j.cbi.2009.08.015

Saravani R, Karami-Tehrani, F, Hashemi M, Aghaei M, Edalat R (2012): Inhibition of phosphodiesterase 9 induces cGMP accumulation and apoptosis in human breast cancer cell lines, MCF-7 and MDA-MB-468. Cell Prolif. 45, 199-206 https://doi.org/10.1111/j.1365-2184.2012.00819.x

Sharma AK, Rohrer B (2007): Sustained elevation of intracellular cGMP causes oxidative stress triggering calpain-mediated apoptosis in photoreceptor degeneration. Curr. Eye Res. 32, 259-269 https://doi.org/10.1080/02713680601161238

Sha J, Pan J, Ping P, Xuan H, Li D, Bo J, Liu D, Huang Y (2013): Synergistic effect and mechanism of vitamin A and vitamin D on inducing apoptosis of prostate cancer cells. Mol. Biol. Rep. 40, 2763-2768 https://doi.org/10.1007/s11033-012-1925-0 
Shen SC, Lee WR, Yang LY, Tsai HH, Yang LL, Chen YC (2012): Quercetin enhancement of arsenic-induced apoptosis via stimulating ROS-dependent p53 protein ubiquination in human HaCaT keratinocytes. Exp. Dermatol. 21, 370-375 https://doi.org/10.1111/j.1600-0625.2012.01479.x

Shymanskyy IO, Lisakovska OO, Mazanova AO, Labudzynskyi DO, Khomenko AV, Veliky MM (2016): Prednisolone and vitamin $\mathrm{D}(3)$ modulate oxidative metabolism and cell death pathways in blood and bone marrow mononuclear cells. Ukr. Biochem. J. 88, 38-47 https://doi.org/10.15407/ubj88.05.038

Srivastava RK, Srivastave AR, Cho-Chung YS (2000): Synergistic effects of 8-Cl-cAMP and retinoic acids in the inhibition of growth and induction of apoptosis in ovarian cancer cells: induction of retinoic acid receptor beta. Mol. Cell. Biochem. 204, 1-9

Steiner M, Priel I, Giat J, Levy J, Sharoni Y, Danilenko, M (2001) Carnosic acid inhibits proliferation and augments differentiation of human leukemic cells induced by 1,25 -dihydroxyvitamin D3 and retinoic acid. Nutr. Cancer 41, 135-144 https://doi.org/10.1207/S15327914NC41-1\&2_19

Suganya N, Mani KP, Sireesh D, Rajaguru P, Vairamani M, Suresh T, Suzuki T, Chatterjee S, Ramkumar KM (2018): Establishment of pancreatic microenvironment model of ER stress: quercetin attenuates $\beta$-cell apoptosis by invoking nitric-oxide signaling in endothelial cells. J. Nutr. Biochem. 55, 142-156 https://doi.org/10.1016/j.jnutbio.2017.12.012

Teisseyre A, Gasiorowska J, Michalak K (2015): Voltage-gated potassium channels KV1.3 - potentially new molecular target in cancer diagnostics and therapy. Adv. Clin. Exp. Med. 24, 517-524 https://doi.org/10.17219/acem/22339

Thillaiappan NB, Chakraborty P, Hasan G, Taylor C (2019): IP3 receptors and $\mathrm{Ca} 2+$ entry. Biochim. Biophys. Acta Mol. Cell Res. 1866, 1092-1100 https://doi.org/10.1016/j.bbamcr.2018.11.007

Tica AA, Dun EC, Tica OS, Gao X, Arterburn JB, Braialoiu GC, Oprea TI, Brailoiu E (2011): G protein-coupled estrogen receptor-1 mediated effects in the rat myometrium. Am. J. Cell Physiol. 301, C1262-C1269 https://doi.org/10.1152/ajpcell.00501.2010

Tsai-Turton M, Nakamura BN, Luderer, U (2007): Induction of apoptosis by $\mathbf{9 , 1 0 - d i m e t h y l - 1 , 2 - b e n z a n t h r a c e n e ~ i n ~ c u l t u r e d ~}$ preovulatory rat follicles is preceded by a rise in reactive oxygen species and is prevented by glutathione. Biol. Reprod. $77,442-451$ https://doi.org/10.1095/biolreprod.107.060368

Villalobos C, Sobradillo D, Hermandez-Morales M, Nunez L (2017): Calcium remodeling in colorectal cancer. Biochim. Biophys. Acta Mol. Cell Res. 1864, 843-849 https://doi.org/10.1016/j.bbamcr.2017.01.005

Wang C, Zhou Y, Guan X, Yu M, Wang, H (2018): $\beta$-estradiol antagonizes the inhibitory effects of caffeine in BMMSCs via the ER $\beta$-mediated cAMP-dependent PKA pathway. Toxicology $394,1-10$ https://doi.org/10.1016/j.tox.2017.11.015

Wang CY, Yang TT, Chen CL, Lin WC, Lin, CF (2014): Reactive oxygen species-regulated glycogen synthetase kinase- $3 \beta$ activation contributes to all-trans retinoic acid-induced apoptosis in granulocyte-differentiated HL60 cells. Biochem. Pharmacol. 88, 86-94 https://doi.org/10.1016/j.bcp.2013.12.021

Wang T, Tsang SH, Chen J (2017): Two pathways of rod photoreceptor cell death induced by elevated cGMP. Hum. Mol. Genet. 26, 2299-2306 https://doi.org/10.1093/hmg/ddx121

Watson EL, Jacobson KL, Singh JC, Ott SB (1999): Nitric oxide acts independently of cGMP to modulate capacitative $\mathrm{Ca} 2+$ entry in mouse parotid acini. Am. J. Physiol. 277, C262-C270 https://doi.org/10.1152/ajpcell.1999.277.2.C262

Wayman CP, McFadzean I, Gibson A, Tucker JF (1996): Inhibition by sodium nitroprusside of a calcium store depletion-activated non-selective cation current in smooth muscle cells of the mouse anococcygeus. Br. J. Pharmacol. 118, 2001-2008 https://doi.org/10.1111/j.1476-5381.1996.tb15636.x

Wei J, Ye C, Liu F, Wang W (2014): All-trans retinoic acid and arsenic trioxide induce apoptosis and modulate intracellular concentrations of calcium in hepatocellular carcinoma cells. J. Chemother. 26, 348-352 https://doi.org/10.1179/1973947814Y.0000000200

Williams WR (2018): Cell signal transduction: hormones, neurotransmitters and therapeutic drugs relate to purine nucleotide structure. J. Recept. Signal. Trans. 38, 101-111 https://doi.org/10.1080/10799893.2018.1431279

Witenberg B, Kalir HH, Raviv Z, Kletter Y, Kravtsov V, Fabian I (1999): Inhibition by ascorbic acid of apoptosis induced by oxidative stress in HL-60 myeloid leukemia cells. Biochem. Pharmacol. 57, 823-832 https://doi.org/10.1016/S0006-2952(98)00351-7

Xiao X, Chen L, Ouyang Y, Zhu W, Qiu, P, Su X, Dou Y, Tang L, Yan M, Zhang H, et al. (2014): Pregnenolone, a cholesterol metabolite, induces glioma cell apoptosis via activating extrinsic and intrinsic apoptotic pathways. Oncol. Lett. 8, 645-650 https://doi.org/10.3892/ol.2014.2147

Xie J, Pan H, Yao J, Zhou Y, Han W (2016): SOCE and cancer: recent progress and new perspectives. Int. J. Cancer 138, 2067-2077 https://doi.org/10.1002/ijc.29840

Xiong A, Yu W, Tiwary R, Sanders BG, Kline K (2012): Distinct roles of different forms of vitamin $\mathrm{E}$ in DHA-induced apoptosis in triple-negative breast cancer cells. Mol. Nutr. Food Res. 56, 923-934 https://doi.org/10.1002/mnfr.201200027

Xu K, Liu XF, Ke ZQ, Yao Q, Guo S, Liu C (2018): Resveratrol modulates apoptosis and autophagy induced by high glucose and palmitate in cardiac cells. Cell Physiol. Biochem. 46, 2031-2040 https://doi.org/10.1159/000489442

Xu H, Qin S, Carrasco GA, Dai Y, Filardo EJ, Prossnitz ER, Battaglia G, DonCarlos LL, Muma NA (2009): Extra-nuclear estrogen receptor GPR30 regulates serotonin function in rat hypothalamus. Neuroscience 158, 1599-1607

https://doi.org/10.1016/j.neuroscience.2008.11.028

Xu Q, Kanthasamy AG, Reddy MB (2011): Phytic acid protects against 6-hydroxydopamine-induced dopaminergic neuron apoptosis in normal and iron excess conditions in a cell culture model. Parkinsons Dis. 2011 https://doi.org/10.4061/2011/431068 
Xu X, Star RA, Tortorici G, Muallem S (1994): Depletion of intracellular $\mathrm{Ca} 2+$ stores activates nitric-oxide synthetase to generate cGMP and Ca2+ influx. J. Biol. Chem. 269, 12645-12653

Yamaguchi T, Kanemitsu H, Yamamoto S, Komatsu M, Uemura H, Tamura, K, Shirai T (2010): N,N'-Bis (2-chloroethyl)-N-nitrosourea (BCNU)-induced apoptosis of neural progenitor cells in the developing fetal rat brain. J. Toxicol. Pathol. 23, 25-30 https://doi.org/10.1293/tox.23.25

Yang DL, Xu JW, Zhu JG, Zhang YL, Xu JB, Sun Q, Cao XN, Zuo WL, Xu RS, Huang JH, et al. (2017): Role of GPR30 in estrogen-induced prostate epithelial apoptosis and benign prostatic hyperplasia. Biochem. Biophys. Res. Commun. 487, 517-524 https://doi.org/10.1016/j.bbrc.2017.04.047

Yang J, Sun Y, Xu F, Liu W, Mai Y, Hayashi T, Hattori S, UshikiKaku Y, Onodera S, Tashiro SI, Ikejima T (2018): Silibinin ameliorates amylin-induced pancreatic $\beta$-cell apoptosis partly via upregulation of GLP-1R/PKA pathway. Mol. Cell Biochem. 452, 83-94 https://doi.org/10.1007/s11010-018-3414-9

Yang Y, Wang W, Liu Y, Guo T, Chen P, Ma K., Zhou C (2012): a-lipoic acid inhibits high glucose-induced apoptosis in HITT15 cells. Dev. Growth Differ. 54, 557-565 https://doi.org/10.1111/j.1440-169X.2012.01356.x

Yoo YM, Jung EM, Ahn C, Jeung EB (2018): Nitric oxide prevents $\mathrm{H} 2 \mathrm{O} 2$-induced apoptosis in SK-N-MC human neuroblastoma cells. Int. J. Biol. Sci. 14, 1974-1984 https://doi.org/10.7150/ijbs.28050

Yoshida 1, Monji A, Tashiro K, Nakamura K, Inoue R, Kanba $S$ (2006): Depletion of intracellular Ca2+ stores itself may be a major factor in thapsigargin-induced ER stress and apoptosis in PC12 cells. Neurochem. Int. 48, 696-702 https://doi.org/10.1016/j.neuint.2005.12.012

Zhang JY, Sun GB, Wang M, Liao, P, Du YY, Yang K, Sun XB (2016): Arsenic trioxide triggered calcium homeostasis imbalance and induced endoplasmic reticulum stress-mediated apoptosis in adult rat ventricular myocytes. Toxicol. Res. 5, 682-688 https://doi.org/10.1039/C5TX00463B

Zhang S, Cao HJ, Davis FB, Tang HY, Davis PJ, Lin HY (2004): Oestrogen inhibits resveratrol-induced post-translational modification of p53 and apoptosis in breast cancer cells. Br. J. Cancer 91, 178-185 https://doi.org/10.1038/sj.bjc.6601902

Zhang S, Wang T, Li SJ (2014): Lansoprazole induces apoptosis of breast cancer cells through inhibition of intracellular proton extrusion. Biochem. Biophys. Res. Commun. 448, 424-429 https://doi.org/10.1016/j.bbrc.2014.04.127

Zhang T, Wu P, Zhang JH, Li Y, Xu S, Wang C, Wang L, Zhang G, Dai J, Zhu S, et al. (2018): Docosahexaenoic acid alleviates oxidative stress-based apoptosis via improving mitochondrial dynamics in early brain injury after subarachnoid hemorrhage. Cell. Mol. Neurobiol. 38, 1413-1423 https://doi.org/10.1007/s10571-018-0608-3

Zhang X, Chen Y, Cai G, Li X, Wang D (2017): Carnosic acid induces apoptosis of hepatocellular carcinoma cells via ROS-mediated mitochondrial pathway. Chem. Biol. Interact. 277, 91-100 https://doi.org/10.1016/j.cbi.2017.09.005

Zhang Y, Xi X, Mei Y, Zhao X, Zhou L, Ma M, Liu S, Zha X, Yang Y (2019): High-glucose induces retinal pigment epithelium mitochondrial pathways of apoptosis and inhibits mitophagy by regulating ROS/PINK1/Parkin signal pathway. Biomed. Pharmacother. 111, 1315-1325 https://doi.org/10.1016/j.biopha.2019.01.034

Zhao YZ, Greenstein JL, Winslow RL (2017): Mechanisms of the cyclic nucleotide cross-talk signaling network in cardiac L-type calcium channel regulation. J. Mol. Cell Cardiol. 106, 29-44 https://doi.org/10.1016/j.yjmcc.2017.01.013

Zhou YP, Teng D, Dralyuk F, Ostrega D, Roe MW, Philipson L, Polonsky KS (1998): Apoptosis in insulin-secreting cells. Evidence for the role of intracellular Ca2+ stores and arachidonic acid metabolism. J. Clin. Invest. 101, 1623-1632 https://doi.org/10.1172/JCI1245

Zolle O, Lawrie AM, Simpson AW (2000): Activation of the particulate and not the soluble guanylate cyclase leads to the inhibition of Ca2+ extrusion through localized elevation of cGMP. J. Biol. Chem. 275, 25892-25899 https://doi.org/10.1074/jbc.M000786200

Received: March 7, 2020

Final version accepted: May 27, 2020 